NBER WORKING PAPER SERIES

\title{
ARE SETTLEMENTS IN PATENT LITIGATION COLLUSIVE? EVIDENCE FROM PARAGRAPH IV CHALLENGES
}

\author{
Eric Helland \\ Seth A. Seabury \\ Working Paper 22194 \\ http://www.nber.org/papers/w22194
NATIONAL BUREAU OF ECONOMIC RESEARCH
1050 Massachusetts Avenue
Cambridge, MA 02138
April 2016

The authors wish to thank seminar participants at USC, Claremont McKenna College, ALEA CELS, RAND and IHEA. Any errors or omissions are the responsibility of the authors. The views expressed herein are those of the authors and do not necessarily reflect the views of the National Bureau of Economic Research.

At least one co-author has disclosed a financial relationship of potential relevance for this research. Further information is available online at http://www.nber.org/papers/w22194.ack

NBER working papers are circulated for discussion and comment purposes. They have not been peer-reviewed or been subject to the review by the NBER Board of Directors that accompanies official NBER publications.

(C) 2016 by Eric Helland and Seth A. Seabury. All rights reserved. Short sections of text, not to exceed two paragraphs, may be quoted without explicit permission provided that full credit, including (c) notice, is given to the source. 
Are Settlements in Patent Litigation Collusive? Evidence from Paragraph IV Challenges

Eric Helland and Seth A. Seabury

NBER Working Paper No. 22194

April 2016

JEL No. I1,K0

\begin{abstract}
$\underline{\text { ABSTRACT }}$
The use of "pay-for-delay" settlements in patent litigation - in which a branded manufacturer and generic entrant settle a Paragraph IV patent challenge and agree to forestall entry - has come under considerable scrutiny in recent years. Critics argue that these settlements are collusive and lower consumer welfare by maintaining monopoly prices after patents should have expired, while proponents argue they reinforce incentives for innovation. We estimate the impact of settlements to Paragraph IV challenges on generic entry and evaluate the implications for drug prices and quantity. To address the potential endogeneity of Paragraph IV challenges and settlements we estimate the model using instrumental variables. Our instruments include standard measures of patent strength and a measure of settlement legality based on a split between several Circuit Courts of Appeal. We find that Paragraph IV challenges increase generic entry, lower drug prices and increase quantity, while settlements effectively reverse the effect. These effects persist over time, inflating price and depressing quantity for up to 5 years after the challenge. We also find that eliminating settlements would result in a relatively small reduction in research and development $(\mathrm{R} \& \mathrm{D})$ expenditures.
\end{abstract}

Eric Helland

Claremont McKenna College

Department of Economics

Claremont, CA 91711

eric.helland@claremontmckenna.edu

Seth A. Seabury

Schaeffer Center for Health Policy and Economics

University of Southern California

635 Downey Way

VPD 414C

Los Angeles, CA 90089

and NBER

seabury@usc.edu 


\section{INTRODUCTION}

The US patent system was created to promote innovation and the advancement of science by allowing innovators to profit from the use of their invention. ${ }^{1}$ Patents provide innovators with exclusive rights to the use of their product and thereby allow them to earn monopoly profits during the patent life. This system was designed to reconcile conflicting policy goals: the need to allow innovators to recoup research and development (R\&D) costs compared to the desire to provide consumers with access to products in efficient markets with competitive products. This tradeoff is particularly acute in the US pharmaceutical market, where the benefits of potentially life-saving pharmaceutical innovation are balanced against the high cost of US healthcare. In recent years, concern over growing healthcare costs has led many to question the value of new pharmaceutical products even for life-saving cancer drugs (c.f. Howard et al., 2015).

This scrutiny has led to many calls for policymakers and regulators to constrain drug prices and promote access for patients. One area in which this has manifested is in efforts to increase regulatory oversight of settlements over patent litigation involving pharmaceuticals. The 1984 Hatch-Waxman Act (the Act) ${ }^{2}$ encouraged the entry of lower-cost generic drugs by allowing generic companies to more easily challenge exiting patents. But as generic entrants have increasingly taken advantage of these provisions, manufacturers have more-and-more responded with "reverse settlements" (also called "pay-for-delay") in which the would-be entrant forgoes their challenge in exchange for a share of the monopoly profits (FTC, 2010, Edlin et al. 2014). This has led the Federal Trade Commission (FTC) to label these settlements as collusive and others to call

\footnotetext{
${ }^{1}$ Specifically, Article 1 section 8(8) of the US Constitution grants Congress the power "To promote the progress of science and useful arts, by securing for limited times to authors and inventors the exclusive right to their respective writings and discoveries."

${ }^{2}$ Although commonly referred to as the Hatch-Waxman Act the technical name of the Act is the Drug Price Competition and Patent Term Restoration Act of 1984.
} 
for banning them outright (Tefferi et al., 2015). However, the implications of reverse settlement on drug prices, utilization and incentives for innovation are not known.

In this study, we examine the impact of reverse settlements on consumers through the entry decisions of generic competitors and on the price and quantity of drugs. We focus on long-term effects, including the potential implications for research and development. Most prior studies on reverse settlements have assumed that the only impact of settlements is to delay first entry (c.f., Reiffen and Ward, 2005; Branstetter et al. 2011 Drake et al. 2014). Yet most major drugs have several indications and methods of application, and many of these might involve patents. If drugs have multiple patents that are subject to challenge, simply examining the first generic entry could overstate or understate the impact for any given molecule. Additionally, in any given patent dispute the settlements in question can delay the entry of generic competitors for several years. The opportunity to put together a binding agreement about the terms and timing of entry also opens the possibility for far greater collusion than would be possible absent the patent case. Finally the incentives of branded manufacturers to invest in research and development may change under settlements.

To address these issues, we test the impact of Paragraph IV challenges-Paragraph IV is the section of Hatch-Waxman under which generic entrants challenge pharmaceutical patents - and settlements on the market dynamics of challenged drugs over an extended period. We treat the selection of drugs chosen for Paragraph IV challenges and the subsequent settlement as endogenous and estimate causal effects using instrumental variables. We use two instruments, one novel and another used more extensively in the literature, to estimate the exogenous effect of Paragraph IV challenges and settlement on the likelihood of entry. The novel instrument comes from a Circuit court split, in which some branded manufacturers had increased ability to settle cases after the 
Circuit courts' decisions according to the location of their corporate headquarters. We demonstrate that branded manufacturers with corporate headquarters in areas where the courts allowed settlements became more likely to settle challenges after the decision. The other instrument is based on the number of patent citations associated with a drug, which has a protective effect on settlement (Hemphill and Sampat, 2011). We test these effects using data on drug price and utilization from a large, nationwide database of commercial medical and pharmacy claims linked to information on Paragraph IV challenges and patents from the FDA, as well as data on settlements that were collected from a several sources.

Our findings suggest that the immediate effect of settlements in Paragraph IV challenges is to completely offset the expected gain in generic entry from the challenge. With our preferred specification, we find that Paragraph IV Challenges increase the probability of generic entry by 68 percentage points (pp) if no challenge occurs, compared to $8.3 \mathrm{pp}$ with a challenge (the latter change not significantly different from zero). However, failing to account for endogeneity implies a positive relationship between settlement and generic entry, reflecting the strong selection bias into settlement agreements. Moreover, we find that the impact of settling Paragraph IV challenges appears to persist over time, well beyond the 180-day duopoly period. In fact, we find that settlements in Paragraph IV challenges reduce generic entry for up to 5 years after the challenge. While this does not necessarily mean that settlements in Paragraph IV challenges really are collusive, the practical impact of settlements appears to be that they inflate prices and depress quantity for up to several years after the challenge, though in the longer term it appears they have little, if any, effect.

We also find that restricting generic entry has a significant impact on the price and quantity of drugs. These large price and quantity effects imply that challenging Paragraph IV challenges has 
significant implications for social welfare. Back-of-the-envelope estimates suggest that settling Paragraph IV challenges reduces consumer surplus by $\$ 835$ million over 5 years. About $\$ 308$ million of this comes from lower producer surplus, with over $\$ 527$ million in deadweight loss. The effects are even larger if we focus on larger branded drugs, which are more likely to be subject to challenges and more likely to result in settlements.

To provide a more complete overview of the potential costs and benefits of settlements, we estimate how restrictions to manufacturers' ability to settle patent litigation might impact investment in the development of new drugs. Specifically, we estimate the impact of the split Circuit Court ruling on the legality of settlements on the research and development expenditures by pharmaceutical manufacturers. We find that manufacturers whose location made it more likely they would be able to settle Paragraph IV challenges had R\&D expenditures that were approximately $0.05 \%$ higher in the year after the ruling and $1 \%$ higher in the subsequent years. Using this estimate combined with the simulated effects of settling Paragraph IV challenges on manufacturer profits, we compute the potential impact on innovation of eliminating settlements and find that it would reduce the number of new products by less than one drug over the next 25 years. With this estimate, eliminating settlements would be welfare enhancing unless the expected value of a new drug were $\$ 35$ billion or more.

The R\&D elasticity we estimate could be low because it reflects uncertainty in the ultimate resolution of the Circuit split. If we use estimates based on the literature, we find that eliminating settlements in Paragraph IV cases could lead to 28 fewer drugs over the next 25 years. With this larger response in innovation, eliminating settlements would only increase societal welfare if the expected value of a new drug were $\$ 750$ million or less. While not conclusive, our findings suggest the potential welfare costs of settlements are high, and are only offset by increased 
innovation if manufacturer $R \& D$ investments are sufficiently responsive to changes in expected profits.

The paper proceeds as follows. The next section reviews the prior literature and provides some background on Paragraph IV challenges and settlements. Section III outlines our empirical approach, data and the instruments that we use. The fourth section describes the results justifying the validity of the instruments and present results on the effects of Paragraph IV challenges and settlements on generic entry and drug price and quantity. Section V describes our results on the potential effects of allowing settlements in Paragraph IV challenges on innovation by drug manufacturers. We conclude with a discussion of the implications of our results.

\section{BACKGROUND}

The 1984 Hatch-Waxman Act made significant modifications to patent law in an attempt to deal with the special market and regulatory forces that surround pharmaceuticals; specifically an increasing concern that the extensive regulatory apparatus that new drugs must pass through before first sale effectively reduces the patent life and hence the ability of companies to recover their research and development (R\&D) costs (Grabowski and Kyle, 2007). Hatch-Waxman was intended as a compromise that allowed makers of new drugs more time to recover their R\&D investment while simultaneously burgeoning the market for generic drugs. The Act balanced these goals by both increasing the effective patent length for pharmaceutical patents and lowering the costs associated with generic entry, the latter by abbreviating the process necessary to obtain approval for a generic product and creating incentives to challenge weak patents. ${ }^{3}$ To increase the effective patent length Hatch-Waxman modified the new drug approval process. As part of the regulatory

\footnotetext{
${ }^{3}$ The concern is that incumbents, wishing to extend their monopoly profits, simply file additional patents to artificially extend their exclusivity, a process known as "evergreening" (Hemphill and Sampat, 2012).
} 
process for determining the extent of FDA granted exclusivity, all companies who wish to market a new therapeutic molecule must file a New Drug Application (NDA). The NDA is required to identify all patents and the length of exclusivity remaining. These patents and their duration are listed in Orange Book. ${ }^{4}$ When the NDA is approved FDA can restore patent length lost in regulatory process and can grant exclusivity of up to five years independent of the remaining patent length although the total post-approval extensions cannot exceed 14 years. The independent grant of exclusivity is designed to protect the data generated by the NDA applicant during the approval process from use by another company in its application for a generic competitor to the drug (Goldman et al 2011). Once data exclusivity is done, an NDA can still have exclusivity remaining on its patents although this need not be the case. It is possible that all patents have expired and only the data restriction prevents entry.

To increase the incentives for generic entry, Hatch-Waxman encouraged potential entrants to challenge patents. These challenges, called Paragraph IV challenges, use the provision of temporary exclusivity as an incentive for generic manufacturers to claim the existing patents are invalid and, after notifying the Food and Drug Administration (FDA), enter the market. The carrot for the challenger is that if they are successful, the entering generic firm which filed the Paragraph IV challenge is entitled to 180 days of exclusivity. That is, the first entrant can earn duopoly rents claiming a share of the incumbent's monopoly profit. The incumbent is required to sue the generic company for patent infringement within 45 days and if the entrant is challenged, the FDA cannot approve a generic product until the earliest of either the patent expiration date, when the court determines there was no patent infringement, or 30 months. Given that these challenges can occur

\footnotetext{
${ }^{4}$ The NDA must contain information on all patents covering the active ingredient, typically called the molecule, the formulation or composition, the method of use. Patents covering the production processes or packaging need not be listed although these are rarely a barrier to entry for generics (see Dorsney, 2012).
} 
years before the last patent covering the drug has expired, there is concern this has led to "prospecting," whereby would-be entrants go hunting for profitable brand-name drugs to challenge rather than seeking out weak patents (Grabowski and Kyle, 2007).

The fact that Hatch-Waxman allows successful challengers 180 days of duopoly rents, leaves room for incumbents and entrants to reach an agreement in which the would-be entrant drops the challenge in exchange for a payment from the incumbent to the entrant. ${ }^{5}$ In practice, the effect of this will most likely be to extend the monopoly rents beyond the 180 days, because without the agreement other generic manufacturers could enter the market and drive profits to competitive levels. Such agreements have become increasingly common (Hemphill, 2007), and have been labeled "reverse settlements" or "pay-for-delay" settlements by the Federal Trade Commission (FTC). ${ }^{6}$ The settlement is effective at preventing entry because only the first challenger can get 180 days of exclusivity, removing the incentive for other entrants to incur the costs of patent litigation.

By the mid-2000s concern over pay-for-delay settlements reached the point where the FTC and the Department of Justice (DOJ) declared these settlements to be collusive and argued that they violate antitrust rules (see Kesselheim et al. 2011). This effort culminated in an FTC report that argued settlements delay generic entry by 17 months on average and cost consumers $\$ 3.5$ billion per year (FTC, 2010). The courts generally upheld pay-for-delay settlements with the $2^{\text {nd }}, 11^{\text {th }}$ and Federal Circuits explicitly allowing settlements and rejecting the FTC's claim of a need to police the settlements for antitrust violations while the $6^{\text {th }}$ and $3^{\text {rd }}$ Circuits explicitly allowed FTC review.

\footnotetext{
${ }^{5}$ Note that this payment could take many forms. For example, Hemphil (2007) notes a number of licensed generics settlements in which the incumbent and entrant negotiate an alternative and presumably more profitable version of generic entry with the settlement.

${ }^{6}$ See also FTC 2010, Bulow, 2004, or Hemphill, 2006
} 
In 2013, the Supreme Court resolved the circuit split in FTC v. Actavis, Inc. ${ }^{7}$ In its ruling, the court adopted a "rule of reason," which stated that while settlements were not per se illegal; the FTC could still challenge them individually on antitrust grounds.

There is currently no consensus on the implications of Hatch-Waxman Paragraph IV challenges to overall societal welfare. Those who criticize the Paragraph IV provisions argue there is concern that increased generic competition is weakening incentives for innovation (see National Academy of Sciences, 2007; Higgins and Graham, 2009; Goldman et al., 2011). It is also possible that the challenges promote costly and sometimes meritless litigation. Supporters of Paragraph IV argue that most activity is around superfluous patents that deserve to be challenged, and this will not significantly affect innovation (see Hemphill, 2006, Hemphill and Sampat, 2011; 2012, FTC 2010).

Hatch-Waxman also provides an expedited method for generic entry. To enter as a generic competitor a company files an Abbreviated New Drug Application (ANDA). The ANDA effectively announces to the FDA and to the branded manufacturer the generic manufacturer's intention to produce a generic version of the drug, either immediately or when exclusivity ends. The entrant has four options, commonly referenced according to the paragraphs in which they appear in Hatch-Waxman (see Branstetter et al. 2011). In this study, we focus on entry - or at least the threat of entry - that occurs under the provisions of Paragraph IV of Hatch-Waxman. To enter the market under those provisions, the entrant alleges that the branded manufacturer's patents are invalid and hence exclusivity has ended or will not be infringed by the generic. ANDAs with Paragraph IV certification may be initiated four years after regulatory approval, but because they

\footnotetext{
${ }^{7}$ FTC v. Actavis, Inc., 570 U.S. __ (2013),
} 
are alleging that the patents covering the drug are invalid or will not be infringed they are entering before the end of the branded drug's asserted market exclusivity period.

Hatch-Waxman contains an inducement for an entrant to attempt a Paragraph IV challenge. The first applicant to submit a complete ANDA receives 180 days of exclusivity that the entrant shares with the incumbent. This exclusivity may be shared by multiple applicants if all file simultaneously. In the case of Paragraph IV challenges, the NDA patent owner has 45 days in which to sue for patent infringement. If suit is initiated within 45 days, the ANDA is subject to a 30-month stay of FDA approval. ${ }^{8}$ This stay may be lengthened or shortened by the court. Prior to 1998 the FDA refused to approve an ANDA application until a patent challenge had been resolved or the 45 day grace period exhausted. Currently the practice is to deal with approval on a case by case basis.

As shown in Figure 1, Paragraph IV challenges remained relatively rare until the late 1990s or early 2000s. There are several reasons for the recent increase in challenges. The first is a series of successful court cases which altered the incentives for filing a Paragraph IV challenge. The first is the Mova case in 1997 in which the court allowed 180 day exclusivity even absent a victory in an infringement case. ${ }^{9}$ As noted above prior to 1998 the FDA required that a Paragraph IV challenger must prevail in any patent litigation before being granted the 180 day exclusivity. As Filson and Oweis (2012) note this "successful defense" requirement was designed to prevent a potential entrant from garnering sales during any period of delay before an injunction was granted. The Mova case found that the FDA's interpretation was inconsistent with Hatch-Waxman and hence any Paragraph IV challenger could begin selling the drug independent of whether their lawsuit had

\footnotetext{
${ }^{8}$ Specifically the generic manufacturer (the ANDA filer) certifies under Paragraph IV that the patents applying to the drug are either invalid or will not be infringed by the ANDA. The FDA then rules on the ANDA application. Once the FDA approves the application the generic filer has twenty days to notify the NDA owner (typically the branded manufacturer). Receipt of this notification triggers the 45 day lawsuit window (see Dorsney (2012)).

${ }^{9}$ See Mova Pharmaceutical Corp. v. Shalala, 955 F. Supp. 128 (D.D.C. 1997)
} 
been filed and such sales would be stopped by an injunction once such a suit had been initiated.

Filson and Oweis, citing the Federal Trade Commission (2002), attribute much of the post 1990s rise to the increased incentives to file produced by the Mova decision. The second major event, according to Filson and Oweis, is Barr Laboratories successful Paragraph IV challenge against Eli Lilly's Prozac patents. Begun in 1996 the challenge and alleged settlement represented the first time that a high-profile drug had lost exclusivity. ${ }^{10}$

Hatch Waxman's principle objective was to balance the tradeoff between the welfare gains from generic entry and the gains to innovation resulting from delaying that entry by extending patent length for drugs which had lost time on patent due to the FDA review cycle (Grabowski and Kyle 2007). Essentially Hatch-Waxman eliminated the requirement for clinical trials for generic drugs if the generic could demonstrate bioequivalence. Prior work has shown that since the passage of Hatch Waxman were has seen a dramatic rise in the likelihood of generic entry (Saha et al. (2006)). There is also evidence that Paragraph IV challenges are becoming a more important source of entry in the pharmaceutical market. By the $2000 \mathrm{~s} 40 \%$ of all generic entry was due to Paragraph IV challenges (Higgins and Graham 2009 and Berndt et al 2007). More recent challenges are occurring earlier in the product lifecycle (Panattoni 2011 Saha et al 2006 Grabowski 2004 Scherer 2001) and are targeting drugs with smaller sales than was previously the case (Grabowski and Kyle 2007). Panattoni (2011) estimates a loss of $\$ 1$ billion to branded firms from Paragraph IV challenges. Branstetter, et al. (2012) estimate gains from Paragraph IV challenges in hypertension

\footnotetext{
${ }^{10}$ The Prozac patent challenges are also interesting because the associated patent infringement case was resolved using a reverse settlement. In 1999 Lilly and Barr reached an agreement on Lilly's claim that Barr had infringed on its patents. Lilly paid Barr and another defendant \$4 million and was able to delay Prozac from becoming generic until 2003 (Hemphill 2007). See also "Lilly and 3 Rivals to Settle Prozac Suit for \$4 Million” David J. Morrow, New York Times, January 26, 1999.
} 
drugs and find that Paragraph IV challenges produces gains in consumer surplus of $\$ 92$ billion or $\$ 133$ dollars per consumer while causing a corresponding loss in producer surplus of $\$ 14$ billion. ${ }^{11}$

Not surprisingly, given the financial stakes involved, most of these challenges end up in litigation. The FTC found that 75 of 104 Paragraph IV challenges it examined ended in litigation (FTC 2002). Of the 53 that were resolved at the time of the FTC study 22 resulted in generic entry. For the other challenges the incumbent was success in suing the potential entrant (and defendant) or the parties reached a settlement. The impact of those settlements remains controversial. Both the FTC (2002) and Bulow (2004) have argued that the settlements are anticompetitive. Drake et al (2014) find that the share prices of branded firms rise. Similarly Bokhari (2013) finds that in a simulation of ADHD drugs prices are 4-4.5 times higher with a settlement than with entry. Finally Hemphill and Sampat (2012) argue that Paragraph IV challenges tend to be aimed at high sales drugs with lower quality patents and later expiring patents suggesting that the gains are potentially even larger is the case for entry that is not triggered by Paragraph IV challenges. Critical to an analysis of Paragraph IV challenges is the impact of entry on investment in research and development. For example Branstetter, et al. (2011) find that increases in generic entry reduce early stage innovation.

From a theoretical standpoint, the legal process for challenging patents with the Paragraph IV process suggests that the challenge and settlement decisions will be nonrandom. There is a well-established economic framework for studying the decisions underlying civil litigation and settlement. ${ }^{12}$ However, the unique payoff structure created by Hatch-Waxman alters the incentives slightly and changes the payout structure. Edlin et al. (2015) outline a settlement model that

\footnotetext{
${ }^{11}$ Other research has focused on entry decisions by generic manufacturers (Morton, 1999, 2000; Grabowski and Vernon, 1992, 1996; Berndt et al., 2003, 2007; Frank and Salkever, 1997; Hurwitz and Caves, 1988; Hudson, 2000; Appelt, 2010). Bokhari and Fournier (2013) estimate the welfare gains due to generic entry more generally and find similarly large welfare gains.

${ }^{12}$ See Micelli (1997) and Spier (2007) for comprehensive surveys of this literature.
} 
demonstrates the implications of these for the selection of drugs to challenges or settlements. For our purposes they key differences with the standard models of settlement are (1) while the standard model predicts that cases will fail to settle only when there are divergent expectations or asymmetric information between litigants, Hatch-Waxman creates an asymmetry in the payoff function that could lead to failure to settle even with perfect information and symmetric beliefs, and (2) contrary to the standard predictions, the more valuable the case (in this context, the more profitable the drug), the more likely a case is to settle. The nonrandom nature of the selection of drugs to challenges and settlements creates a selection problem for the empirical work which we address through instrumental variables.

\section{EMPIRICAL FRAMEWORK}

\section{III.A. Approach}

We model the relationship between Paragraph IV challenges and settlements on generic entry using the following regression model:

$$
\text { entry }_{i t}=\beta_{e}^{c} \text { challenge } e_{i t}+\beta_{e}^{s} \text { settle }_{i t}+\varphi_{p} X_{i t}+\mu_{i}+\lambda_{t}+\epsilon_{i t}
$$

Here entry $y_{i t}$ represents the entry decision of potential generic manufacturers of drug $i$ in time $t$. The vector $X$ includes drug-specific characteristics that influence the potential sales of a drug. The parameters $\mu$ and $\lambda$ are fixed effects for drug or drug class (denoted by $m$ ) and time, respectively. The variable challeng $_{i t}$ is a flag indicating that drug $i$ had been challenged at least once by time $t{ }^{13}$ The variable settle $_{i t}$ represents whether the challenge was also accompanied by a settlement. ${ }^{14}$ Thus, we can interpret $\beta_{e}^{c}$ as representing the impact of a challenge in the absence of a settlement

\footnotetext{
${ }^{13}$ Note that by specifying challenge as ever being challenged, we are estimating the effect of the first challenge on outcomes.

${ }^{14}$ Note that because you can only have a settlement after a challenge occurs, the variable settle $e_{i t}$ can be interpreted as an interaction term challenge $e_{i t} \times$ settle $_{i t}$.
} 
on generic entry, whereas $\beta_{e}^{s}$ represents the differential impact of a challenge when a settlement occurs. We expect Paragraph IV challenges to make entry more likely, so $\beta_{e}^{c}>0$, while settlements should delay entry, at least temporarily, so $\beta_{e}^{s}<0$. Because $\beta_{e}^{s}$ represents an interaction term, we tested the combined effect of Paragraph IV challenges with settlements as $\beta_{e}^{c}+\beta_{e}^{s}$. This combined term could be positive, zero or negative, depending on whether settlement had only a small effect (or no effect) on entry, whether it completely offset the beneficial effects of challenges on entry, or whether it was sufficiently strong as an entry deterrent as to reduce the long term number of entrants in the market, respectively. ${ }^{15}$

The model represented by Equation 2 implicitly assumes that there is no unobserved heterogeneity in drugs that would drive both entry decisions and Paragraph IV challenge and settlement decisions. But as noted above, we expect that both challenge and settlement decisions will be driven in large part by expected drug profitability of a drug. In the empirical analysis we include predictors of drug profitability (e.g., the size of the potential market for the drug), but this is unlikely to capture all the unobserved heterogeneity in drug characteristics. Thus, to obtain consistent estimates of the causal impact of challenges and settlements on generic entry and market outcomes, we need a set of instruments that drive litigation decisions but are otherwise unrelated to drug sales. We use instruments based on the strength of a drug's patent portfolio and judicial decisions about the legality of FTC oversight of settlements to provide variation in the incentives to

\footnotetext{
${ }^{15}$ Note that with the application to generic entry we are using 2SLS to estimate a linear probability model with endogenous regressors. The debate concerning the limitations and benefits of the linear probability model itself are well known and discussed in detail in Wooldridge (2002), Angrist and Pischke (2009) and others. However, these limitations are more vexing for binary models with potentially endogenous regeressors. The key problem, in addition to the well-known issue that the LPM predicted probabilities are not constrained to be between zero and one, is that all discrete dependent variables models have an unidentified scale factor that multiplies every coefficient and potentially makes the estimation of structural parameters uninformative. Given the restrictive assumptions necessary to rectify this limitation, Angrist (2001) and Wooldridge (2002) recommend estimating the model via 2SLS in lieu of alternative approaches. As Wooldridge (p472) notes "This procedure is relatively easy and might provide a good estimate of the average effect." We note that, presumably, this problem should not be an issue with our specification estimating the number of drugs entering, and the results are broadly consistent across the two specifications.
} 
challenge and settle challenges that is not otherwise related to sales. In the remainder of this section we describe the data we use to estimate this model and outline our instrumental variables strategy.

One limitation of the model in Equation 2 is that it assumes a constant effect of Paragraph IV challenges and settlements over time. Specifically, since the binary indicators "turn on" after the first challenge (or settlement) and stay on, the coefficients $\beta_{e}^{c}$ and $\beta_{e}^{s}$ represent the average effect of challenge and settlement over the entire post-challenge period. To test whether the effects of challenge or settlement diminish over time, we also estimate the following dynamic model:

$$
\text { entry }_{i t}=\beta_{j}^{c} \text { challenge }_{i t-j}+\beta_{j}^{S} \text { settle }_{i t-j}+\varphi_{p} X_{i t}+\mu_{i}+\lambda_{t}+\epsilon_{i t}
$$

Here challenge $_{i t-j}$ and settle $_{i t-j}$ are variables indicating whether there was a challenge or settlement, respectively, $j$ years previously. We estimate 5 years of lags using separate regression models, estimating separate models because we lacked identifying variation to combine all lag terms in a single instrumental variable model. If Paragraph IV challenges or settlements have only a short-term impact on entry, we would expect the coefficient estimates to decline with longer lag periods.

\section{III.B. Data sources}

We use data from several sources to construct a drug-year level file that includes information on generic entry, drug price and quantity, drug characteristics, patent information and Paragraph IV challenges and settlements. Our information on the date of generic entry come from the FDA Center for Drug Evaluation and Research’s Drugs@FDA database. The Drugs@FDA database contains the information that is available in the FDA's "Orange Book," which lists the NDC codes, active ingredient, manufacturer, strength, dose, etc. of pharmaceutical products. ${ }^{16}$ The key advantage of the Drugs@FDA over the annual editions of the Orange Book is that the annual

\footnotetext{
${ }^{16}$ See http://www.accessdata.fda.gov/scripts/Cder/ob/default.cfm, accessed on May 28, 2014.
} 
editions remove drugs that are no longer on the market, while Drugs@FDA retains the information. We treat a molecule as having generic entry if the Drugs@FDA database lists any generic entrants. As a secondary measure, we computed the total number of generic manufacturers listed in Drugs@FDA for the molecule-year, which we term the "number of generic entrants."17

The data on our market outcome variables, the price and quantity of drug sales, come from a large database of private-sector health insurance claims from 1998 to 2008 (the Ingenix-Touchstone database). These data are drawn from the complete set of pharmacy benefit claims of all individuals covered by a sample of over 50 large employers. The data include all major plan types (e.g., HMO, PPO, etc.), and include members in all 50 states plus the District of Columbia. The data include the claims for employees as well as dependents and other beneficiaries, totaling more than 20 million covered lives over our entire sample. This allows us to conduct analysis for specific classes of medications across the US. These data have been used in a number of prior analyses of pharmaceutical drug utilization (c.f., Joyce et al., 2002; Goldman, 2004; Goldman, 2006a; Goldman, 2006b; Goldman, 2007).

We collapse the claims-level data to the ingredient, or molecule, level. ${ }^{18}$ Specifically, we take all pharmacy claims at the National Drug Code (NDC) level, and aggregate the expenditures, number of pills, number of filled prescriptions and number of patients prescribed any quantity of the drug to the molecule-year level. The NDC code can be used to identify the generic status of specific molecules, and some molecules may have both generic and branded sales at a given point in time. To measure the price of a drug, we sum the total expenditures - that is, the expenditures of both the health plan and the out-of-pocket expenditures of beneficiaries - and divide by the number

\footnotetext{
${ }^{17}$ Note that this definition captures all approved ANDAs and as such the drug need not have gone to market to be included.
} 
of units purchased. To normalize the price across prescriptions of varying length, we defined units as the number of 30-day equivalent prescriptions sold of the drug in our data.

Our patent information comes from various editions of the Orange Book beginning in 1984. Because the Orange Book is updated annually we are able to construct a rolling list of asserted patents removing or adding patents as the Orange Book changes. This data can be linked directly to patent litigation and settlements via the patent number. ${ }^{19}$

Our data on Paragraph IV challenges come from the FDA. One issue is that prior to 2000 the FDA did not list the year of the challenge but merely kept a running list of challenges. Using previous editions of the list we are able to construct the year in which a particular challenge joined the list. In addition we verified these data, and those challenges listed on the first FDA list, using media accounts contained in Lexis/Nexus.

Because entry requires that data exclusivity ends prior to entry (see Goldman et al. 2011) we include the number of years remaining on the original market exclusivity as stated in the Orange Book at the time of first issue in our price and quantity regressions. However, any given molecule may have several different exclusivity dates since there may be several NDAs within a molecule. In addition an incumbent may file additional patents in order to preserve exclusivity. Because this is endogenous to eventual sales—-for example, an incumbent might be more likely to file additional patents for a successful drug - we utilize only the initial exclusivity. Thus a molecule may have Paragraph IV challenges after the end of our exclusivity variable.

Our data on litigation and settlement come from a variety of sources. The Stanford Patent

\footnotetext{
${ }^{18}$ One difficulty with this approach is that a single molecule is often used in multiple drugs (e.g diltiazem (Cardizem) comes in a tablet, injectable, two extended release capsules and an extended release tablet. Since challenges can cover some, or all, of the drugs once concern is that our molecule-level analysis lumps together generic entry on drugs that are off patent with Paragraph IV challenges on another drug in the same molecule. Ideally we would estimate the model at the drug level however our early Paragraph IV data and much of our settlement data identify the molecule but not the specific dose of the drug.

${ }^{19}$ We also verify settlements using drug specific information contained in 10k and media accounts. See below.
} 
Litigation Data, derived from the Federal Courts' Public Access to Court Electronic Records (PACER) database on filings, provides information on patent numbers challenged and a prediction as to whether the case settled. The limitation of the Stanford data is that it begins in 2000 . We supplemented it with Patent Office data on litigation (see Lanjouw and Schankerman 2001) and an extensive review of court records, 10k filings and industry news in Lexis/Nexus. Although we cannot be sure our list is comprehensive, we are able to identify all settlements contained in other surveys of reverse settlements (Hemphil, 2007). One drawback to our method is that we often do not know the terms of the settlement. For this reason we can only identify whether a case settled but not if there was an explicit delay of entry or the amount of the payment.

Additionally, we include information on the side effects and warning labels on drugs as controls for other factors impacting demand and competition for the drug in question. Our data on side effects are from the FDA's Adverse Event Reporting System (AERS) and covers the years 1996-2008. The AERS data tabulates these annual adverse event reports by drug. We consider six overlapping categories of adverse events: deaths, hospitalization, disability, congenital anomalies, life threatening adverse drug reactions, and events requiring additional medical intervention to prevent permanent injury. The data on warning labels come from MedWatch Reports which are available on the FDA website. Our data cover the warnings in effect during between 1996 and 2008. We classify warning labels as covering Black Box warnings, contraindications, general warnings, precautions while taking the drug, potential adverse reactions, a medication guide, a patient package insert, recommendations on dosage and administration, information on clinical pharmacology, recommendations on indications and usage, information on overdose, information on drug abuse and dependence, references to other warnings and references to clinical studies. The 
idea is that the presence of each on a warning label provides potentially negative information to doctors and consumers about the drug.

Another important covariate that will influence a drug's price and quantity is the size of the market. We construct a measure of the potential market at the therapeutic class level, following previous work by Acemoglu and Linn (2004). The assumption is that the market structure, entry, price and quantity, are in part determined by expectations of future demand. The potential market measure captures the income of the group that is most likely to take the drug in the future. We constructed this variable at the class-year level using the same approach as Acemoglu and Lin (2004) and linked to each drug at the class level. ${ }^{20}$

Descriptive statistics for the data are presented in Table 1. The data are presented overall and broken into three distinct subsamples: drugs that were subject to at least one Paragraph IV challenge without an identified settlement, drugs with a Paragraph IV challenge and a settlement, and drugs that were never challenged. ${ }^{21}$ There are clearly differences between the subsamples. Drugs with greater annual sales are more likely to be challenged and are more likely to have a settlement. A similar relationship holds if we focus on the potential market; the potential market is highest for drugs that have a challenge and settlement and lowest for drugs that are never challenged. Also, although the percentage of years with generic competition measured by either Drugs@FDA are similar across groups, there are clear differences across categories in terms of the number of generic entrants. Drugs with a challenge but no settlement have an average of 5.82

\footnotetext{
${ }^{20}$ Specifically, the potential market for therapeutic class is defined as Potential market $c_{c t}=\sum_{a} u_{c a} i_{a t}$, where $u_{c a}$ is the share of use of the drug class $c$ by individuals in age catagory $a$ and $i_{a t}$ is the income of age group $a$ in year $t$. Following Acemoglu and Linn, we use five age catagories: 0-20, 20-30, 30-50, 50-60 and 60+. The data on drug utilization by age and gender come from the Medical Expenditure Panel Survey (MEPS), while the data on annual income come from the March Supplement of the Current Population Surve (CPS). We use the MEPS to construct the potential market (rather than data from the private claims database) because it includes information across all insurance types, including the uninsured, making it more representative of the full potential market than data from a single private insurer.

${ }^{21}$ Note that drugs identified as having a challenge and/or settlement in Table 1 include the years prior to the challenge and hence Paragraph IV and settlement do not equal 1 in their respective columns.
} 
gentric entrants, while those with a settlement have only 4.36 and those that are unchallenged have 2.58. The raw data clearly suggest differences in drugs that face a Paragraph IV challenge compared to those that do not.

In Table 2, we further examine the possibility of selection by comparing rates of challenge and settlement across drugs of different potential market size. For each drug, we take the mean value of potential market size (as defined above) across all years and then stratify drugs into quintiles of potential market. We then compute the mean rate of Paragraph IV challenges for drugs within each quintile, overall and by time from the end of the initial patent exclusivity date. The data clearly indicate selection across drug profitability in terms of the likelihood of a Paragraph IV challenge. ${ }^{22}$ Just over $34 \%$ of drugs in the top qunitile of potential market have a Paragraph IV challenge, compared to $8.5 \%$ in the bottom quintile. As expected, challenges are more frequent after the end of the initial exclusivity date, particularly for the more profitable drugs. Prior to the end of the initial exclusivity period, just $22 \%$ of drugs in the top quintile have a Paragraph IV challenge compared to $40.9 \%$ in the first five years after. The first five years after the end of exclusivity appear to be when most of the challenges take place, as there is little difference between 1-5 years after the end of exclusivity and 5+ years. This is consistent with Paragraph IV challenges being used as tools to combat evergreening tactics to extend functional patent life (Hemphill and Sampat, 2012).

The bottom row reports the percent of challenged drugs that also had a settlement. The data suggest a positive relationship between profitability and settlement. Just $4.2 \%$ of the challenged drugs settle in the bottom quintile, compared to $25.7 \%$ in the top quintile. This is noteworthy

\footnotetext{
${ }^{22}$ To confirm the relationship between potential market and profitability, we computed total sales by quintile as well and found that drugs with higher potential market did indeed have higher sales. For instance, the estimated sales per drug-year was $\$ 5.4$ million in the top quintile of potential market compared to $\$ 376 \mathrm{~K}$ in the bottom quintile.
} 
because, as discussed in Section 2.3 above, the standard litigation and settlement model suggests a lower settlement rate for higher stakes cases. ${ }^{23}$ While there other unobserved factors that could be correlated with profitability and settlement rates ${ }^{24}$, this is consistent with the idea that the asymetric payoffs in Paragraph IV challenges promoting settlement for higher sales products.

\section{III.C. Instruments}

To control for the endogenous nature of our variables of interest we estimate the model using instrumental variables based on two sources: patent strength as measured by the number of citations, and a federal court circuit split regarding the validity of FTC oversight of settlements in Paragraph IV challenges. The logic behind using patent strength is straightforward; a challenge is more likely to be successful if the underlying patent is weak, so the case has higher expected value. Hemphill and Sampat (2011) provide evidence that challenges are more likely against weaker patents, measured by the number of citations, and drugs with fewer remaining patents. Our data on patent quality comes from the NBER patent citations database (see Jaffe and Trajtenberg, 2002). A widely used measure of patent quality is the number of patents that cite the patent in question (see Hemphill and Sampat, 2011). The NBER data and its subsequent updates contain 3 million patents and 16 million citations. We match data on the number of citations to individual molecules using the patent information in the Orange Book.

We include a variety of measures of patent strength as potential instruments. Specifically, we include the average citations relative to the patent's cohort under the assumption that earlier patents have more time to accumulate citations relative to late patents. We also include the unadjusted average citation of all the patents listed in the Orange Book, the citations of the patent

\footnotetext{
${ }^{23}$ We also compared the settlement rate for drugs with challenges over different periods before and after the end of exclusivity and did not find any obvious trend; the overall settlement rate was about $20 \%$ before and after exclusivity end. This is likely due to the fact that the duopoly period for successful challenges is relatively short.

${ }^{24}$ For example, if there were a positive and convex relationship between defense costs and potential judgment it could generate a positive relationship between settlement rates and stakes.
} 
with the fewest citations out of the Orange Book listed patents for the drug, the total citations for all list patents for the drug and finally the total number of patents in the Orange Book. Finally, we interact patent strength with the time remaining on exclusivity.

Our exclusion restriction for settlements has not, as far as we know, been used as an instrument before. We take advantage of the above mentioned circuit court decisions. During the 2000s the FTC asserted the right to review settlements of antitrust violations. In 2002 the $11^{\text {th }}$ Circuit found that FTC did not have the authority to review settlements. In 2005 the $2^{\text {nd }}$ Circuit issued a similar ruling. The $6^{\text {th }}$ Circuit explicitly ruled that the FTC did have the authority to review settlements resulting in a Circuit split resolved by the Supreme Court in $2013 .{ }^{25}$ Our instrument assumes that the $11^{\text {th }}$ and $2^{\text {nd }}$ Circuit rulings reduce the threat of an FTC review and hence increase the profitability of reverse settlements in cases covered by these regions. ${ }^{26}$ To capture this effect we include an indicator equal to 1 if the corporate headquarters of the incumbent is in one of these two Circuits. The logic is that due to the doctrine of forum non conveniens (inconvenient forum) antitrust cases are easier for the defendant company to move to locations where the company has major operations.

\section{RESULTS}

\section{IV.A. Results on instrument validity}

We begin by presenting some empirical results on the validity of our instruments. We demonstrate the first-stage power of our instruments with linear probability models of Paragraph IV challenges and settlement as a function of the Circuit split and our patent strength measures. These regressions are of the form:

\footnotetext{
${ }^{25}$ Two other Circuits, the $3^{\text {rd }}$ and the Federal Circuit, have also weighed in but these decisions occurred after our sample period.

${ }^{26}$ The FTC essentially assumes this is true in its 2010 report by assuming that the decisions increase the likelihood of settlement.
} 


$$
y_{i t}=\alpha H Q_{i t}+\omega_{1} \text { strength }_{i t}+\omega_{2} \text { timexstrength }_{i t}+\varphi X_{i t}+\mu_{m}+\gamma_{t}+\epsilon_{i t}
$$

where $y_{i t}$ is an indicator variable equal to 1 for all years after the first challenge in the challenge equation or an indicator variable equal to one for all years after the settlement. The variable $H Q_{i t}$ is an indicator equal to one if the incumbent has its corporate headquarters in the $11^{\text {th }}$ Circuit post

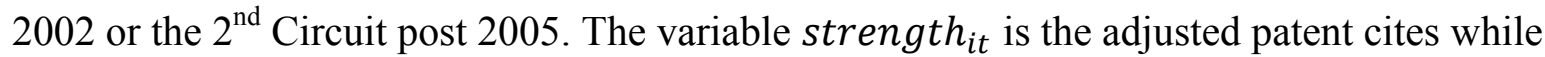
time $\times$ strength $_{i t}$ is the adjusted sites interacted with the time until the end of the initial exclusivity period. The other covariates include the drug characteristics and class and year fixed effects as discussed above. ${ }^{27}$

We provide some graphical support for the importance of the Circuit split on the probability that a Paragraph IV challenge results in settlement in Figure 2. The figure compares the percent of Paragraph IV challenges with a settlement according to the location of the branded manufacturer's corporate headquarters. We compare the $2^{\text {nd }}, 6^{\text {th }}$ and $11^{\text {th }}$ circuits as well as all others grouped together. Importantly, the proportion of all Paragraph IV challenges ending in settlement increases dramatically in $2^{\text {nd }}$ Circuit post 2005, with comparatively little change in the other circuits. This suggests that the $2^{\text {nd }}$ Circuit decision is a plausible instrument for the likelihood that a challenge results in settlement.

Figure 3 illustrates the relationship between patent strength and the likelihood that a drug patent is challenged according to the year from the end of the initial patent exclusivity period. Specifically, we stratify drugs into three groups: those with a patent with zero adjusted citations, those with citations below the median number conditional on non-zero citations (about 0.7), and those with greater than the median number. ${ }^{28}$ There are two key facts to notice from the figure.

\footnotetext{
${ }^{27}$ In particular we include year fixed effects to capture the general trend in settlements. It is clear that after the $2^{\text {nd }}$ and $11^{\text {th }}$ Circuit rulings the number of settlements increased perhaps due to a general sense that antitrust policy was becoming more lenient.

${ }^{28}$ Recall that patent citations are adjusted relative to other patents in the same cohort, which is why they are not restricted to integer values.
} 
The first is that, somewhat counterintuitively, patent strength is positively associated with the probability that a drug experiences a Paragraph IV challenge. In principle, this is contrary to our expectations that entrants would be less willing to challenge drugs with a number of patents, so called patent thickets. However, this is consistent with Hemphill and Sampat (2012), who demonstrate a greater likelihood of challenge among supplemental patents - as opposed to the patent for the novel active ingredient—-so drugs with more patents (and more patent citations) are more likely to experience a challenge. However, this effect is most prominent after the initial exclusivity period ends, meaning that as the number of years left on exclusivity increases, stronger patents have some deterrent effect on challenges. Also, consistent with Hemphill and Sampat (2012), it is at least suggestive that much of the Paragraph IV challenge activity is driven by combating evergreening tactics by manufacturers, rather than attempting to undermine the original patent.

The key findings from the first-stage regressions are presented in Table 3. Columns 1 and 2 report the estimated impact of the instruments on the probability of Paragraph IV challenges with class and drug fixed effects, respectively. In general, the first-stage results supported the validity of the instruments. Consistent with Figure 3, the cumulative effect of the adjusted number of patents on patent challenges was positive. However, there was a strong negative interaction term, confirming the finding in the figure that patent strength is less of a deterrent the closer a drug gets to the end of exclusivity (or the further the drug exceeds it). This relationship held with therapeutic class or drug fixed effects. ${ }^{29}$

\footnotetext{
${ }^{29}$ Note that the actual number of cites drops out of the fixed effect model because this measure did not vary sufficiently for the same drug over time within our sample, but the interaction term provided sufficient identifying variation to estimate the instrumental variables model with drug fixed effects.
} 
Columns 3 and 4 report the estimated impact of the instruments on the probability of a settlement with class and drug fixed effects, respectively. Note that we only observed a settlement if there was a challenge, so the coefficients on settlement reflect both the impact of each variable on whether a challenge occurred net of the impact on settlement. However, it is noteworthy that the Circuit split variable has a strong and persistent impact on settlements, while the patent strength does not. For example, the coefficient on the time between patent citations and time from exclusivity end was small and not statistically significant for settlements. However, having a corporate headquarters in the $11^{\text {th }}$ or $2^{\text {nd }}$ Circuit increases the likelihood of a challenge and settlement by close $40 \%$ regardless of the specification.

The bottom row reports the first-stage F-test of the instruments' joint significance. Bound, Jaeger, and Baker (1995) and Staiger and Stock (1997) suggest that an F statistic of greater than 10 is required to mitigate concern about weak instruments. While this critical value is only relevant for a single endogenous variable, the fact that the F-test was strong for both endogenous variables individually suggests that weak instruments are unlikely to be a problem for us.

\section{IV.B. Results on Generic Entry}

Figure 4 illustrates the relationship between Paragraph IV challenges, settlements and generic entry. The figure shows the percent of drugs with at least one generic entrant by year from the end of the initial exclusivity period according to whether or not there was a challenge, and whether or not the challenge resulted in a settlement. Consistent with the earlier discussion, drugs that never face a Paragraph IV challenge are relatively less likely to experience generic entry, even 10 years after the exclusivity end date. Drugs with a Paragraph IV challenge that also settle are less likely to experience generic entry than those that fail to settle, and this effect lasts from the last few 
years prior to the end of exclusivity until 2-3 years after it ends. At that point, there is little difference in generic entry between drugs with or without a settlement.

The relationship between Paragraph IV challenges and settlements and generic entry is consistent with the notion that settlements delaying generic entry, and that the effect persists longer than the allowed duopoly period..$^{30}$ In fact, the figure suggests that generic entry could be delayed by up to several years after the initial challenge as a result of settlement. This is somewhat surprising, given that the period during which the branded manufacturer and initial entrant share the market is relatively brief. One potential explanation for this is that the opportunity for duopoly rents is a relatively strong motivation for filing a Paragraph IV challenge and entering the market, and that taking that opportunity away reduces the incentives for new entrants. ${ }^{31}$

We present our baseline regression estimates of the effect of Paragraph IV challenges and settlements on generic entry in Table 4. Each column represents the results with a different combination of dependent variable (any entry versus number of entrants), estimation method (OLS or 2SLS) or fixed effects (class or drug). The first row represents the effect of Paragraph IV challenges, the second row reports the effect of settlements, while the third row reports the combined effect of a challenge with a settlement. The first row indicates that Paragraph IV challenges increased the probability of generic entry in the post-challenge period regardless of specification. The OLS estimates suggest up to a 0.3 percentage point increase in the probability of entry, while the 2SLS results suggest a stronger effect of up to 0.7 (the specifications with drug fixed effects are smaller and statistically significant only in the OLS specification). Similarly, the OLS results suggest that the number of entrants increases by up to 2 entrants, while the 2SLS

\footnotetext{
${ }^{30}$ Moreover, the effect appears longer on average than the 17 months estimated by the FTC (FTC, 2010).

${ }^{31}$ In particular, it might reduce the incentives for potential entrants to go through the costs of combating a branded manufacturer's evergreening tactics.
} 
estimates indicate an increase of up to 12 new generic entrants (here the results are slightly larger and statistically significant at the $10 \%$ level even with drug fixed effects).

The estimated impact of settlements differs significantly between the OLS and 2SLS models. Using any generic entry as the dependent variable, the effect of settlement is to reduce the effect of Paragraph IV challenges on the probability of entry by 0.6 percentage points in the 2SLS model with class fixed effects (Column 3), but neither challenge nor settlement have a significant effect on the probability of entry if drug fixed effects are used (Column 4). The findings are more pronounced when the number of entrants is used as the dependent variable. In the 2SLS model with class or drug fixed effects, a settlement reduces the effect of Paragraph IV challenges on the number of entrants by approximately 10.3 or 7.7 , respectively. Importantly, the third row demonstrates that, for all of the 2SLS specifications, settlement completely offsets any positive effect of Paragraph IV challenges on generic entry, as all estimates of the combined coefficients are small or negative and not statistically different from zero.

These findings are consistent with the results of Hemphill and Sampat (2012) that Paragraph IV challenges speed up entry and make up the majority of the difference between effective and actual patent life. Our 2SLS estimates indicate that Paragraph IV challenges lead to an increase in both the probability of entry and number of entrants. Additionally, our estimates consider the effect of settlement and suggest that they might even more than offset the effect of Paragraph IV challenges on the number of entrants (i.e., the combined coefficient is negative in Columns 7 and 8). On the surface, this appears to support the fears that these settlements act collusively and undermine the competitive effects of Paragraph IV challenges. While the negative net effect of the settlement on entry is small and not significant, at the very least our findings 
indicate that settlements are able to more or less entirely eliminate the impact of Paragraph IV challenges on the level of generic competition for a drug.

In Table 5 we report the findings of the dynamic model that allows the effects of Paragraph IV challenges and settlements to vary over time. The table reports the estimated effect of a challenge with no settlement and with a settlement on the probability of any entry and the number of entrants. For simplicity we report only the 2SLS results with class fixed effects. The top row reports the contemporaneous estimate of the challenge and settlement on entry (taken from Table 4), while the next rows report the estimated lagged effects from 1 to 5 years.

There are two important points to note from the table. The first is that the effect of a Paragraph IV challenge with no settlement is stable over time. A challenge with no settlement is associated with a 0.58 to 0.70 increase in the probability of any generic entry over the 5 years of lags, with no indication of a trend over time. This indicates that, absent a settlement, a Paragraph IV challenge is associated with an immediate and persistent increase in generic competition for branded products. The second point to note is that while settlements delay entry, this effect only appears to last for a few years. The combined effect of a Paragraph IV challenge with a settlement on the probability of any generic entry is significantly smaller and not statistically different from zero for the first 3 years of lags, but for the 4-year lag and 5 year lag the effect is negligible (the effect of a challenge with a 5 year lag actually exceeds that of the challenge with no settlement). Using the number of drugs as the dependent variable, the effect of a challenge with a settlement is still not statistically different from zero with a 4 or 5 year lag, but the difference in coefficient estimates suggests no more than a decrease in the number of entrants by 1 or 2 . This suggests that while settlements do serve to reduce the amount of generic competition for a branded product, this 
effect is short-term in nature and the long term amount of generic entry is influenced much more by whether or not a challenge occurred, and not by whether or not a settlement took place.

\section{IV.C. The Effects of Entry on Drug Price and Quantity}

The effect of Paragraph IV challenges and settlements on consumer welfare will depend largely on the effects on price and quantity, which will in turn be driven by the amount of generic entry. It is well-established that generic entry reduces the price of branded products, which should also result in an increase in the quantity consumed (absent other factors such as reduced marketing for generic products). ${ }^{32}$

We estimate the impact of generic entry on log price and quantity using the following specification:

$$
\begin{aligned}
& p_{i t}=\beta_{p}^{e} \text { entry }_{i t}+\varphi_{p} X_{i t}+\mu_{m}^{p}+\lambda_{t}^{p}+\epsilon_{i t}^{p} \\
& q_{i t}=\beta_{q}^{e} \text { entry }_{i t}+\varphi_{q} X_{i t}+\mu_{m}^{q}+\lambda_{t}^{q}+\epsilon_{i t}^{q}
\end{aligned}
$$

These models are analogous to Equations 2 above, except we estimate the impact of generic entry on price and quantity. When estimating this model using 2SLS, we treat entry as endogenous to price and quantity and instrument for entry using the predictors of Paragraph IV challenges and settlements. That is, we estimate the first-stage equation:

$$
\text { entry }_{i t}=\alpha^{e} H Q_{i t}+\omega_{1}^{e} \text { strength }_{i t}+\omega_{2}^{e}{\text { time } \times s t r e n g t h_{i t}}+\varphi^{e} X_{i t}+\mu_{i}^{e}+\gamma_{t}^{e}+\epsilon_{i t}^{e}
$$

This model is structured similarly to the first-stage equation represented by 3 above, except we replace challenge and settlement with entry as the dependent variable. In this context, the model serves as the first stage equation for an instrumental variable model of the effect of generic entry on price and quantity. The underlying assumptions about the instruments are analogous, in that they

\footnotetext{
${ }^{32}$ For example, see Lakdawalla and Phillipson (2012).
} 
only affect price and quantity through their effect on generic entry, which is driven by the effect on Paragraph IV challenges and settlements.

We report the estimates of entry on price and quantity in Table 6 . The top panel reports the results for the price per prescription while the bottom panel reports them for the quantity of prescriptions sold. In the first two columns we report the estimates of the model via OLS and 2SLS, respectively, using any generic entry.

The OLS results suggest that entry reduces log price in the post-entry period by 0.397 and by 1.433 using 2 SLS. Interpreting in percentage terms, the 2SLS estimate suggests that generic entry results in approximately a 74\% decrease in price. ${ }^{33}$ In Columns 3 and 4 we estimate the model using the number of generic entrants and find that each new drug reduces price by about $10 \%$ using the 2SLS estimates. The fact that the OLS estimates are less than the 2SLS estimates is consistent with the hypothesis that higher priced and more profitable drugs are more likely to attract generic entry.

The bottom panel reports the findings for the effect of generic entry on drug quantity, as measured by the total number of prescriptions. The table demonstrates a positive relationship between generic entry and quantity sold. The 2SLS estimates suggest a strong relationship between entry and quantity - the coefficient on any generic entry indicates an increase in log prescriptions of 1.487 which corresponds to more than a $300 \%$ increase. The coefficient on the number of entrants suggests that each new entrant is associated with about a $24 \%$ increase in quantity sold.

Combining the findings from the results on the effects of Paragraph IV challenges and settlements on generic entry and the effects of generic entry on drug price and quantity suggests that settlements could have important implications for consumers and for societal welfare. To

\footnotetext{
${ }^{33}$ In the log-linear model we estimate, we convert the coefficient $-\mathrm{b}$ to a percentage decrease as 1-exp(-b).
} 
better understand these effects, we simulated the impact of a Paragraph IV challenge on consumer surplus, producer surplus and deadweight loss. We make two critical assumptions to estimate welfare effects. First, we follow Lakdawalla and Philipson (2012) and assume that demand for the drugs is linear. If this is violated, the welfare effects will be mis-specified, with the degree of error depending on the degree of nonlinearity of demand. The second assumption is that the post-entry price is the competitive price - that is, that it equals (constant) marginal cost. If the post-entry price exceeds marginal cost, then our estimates will overstate the impact of entry on producer surplus and understate the impact on deadweight loss. ${ }^{34}$

To estimate these effects, we applied the 2SLS estimates of the impact of generic entry on price and quantity from Table 6 to the drugs in our sample to get the post-entry price. Specifically, we converted these estimates to percentage reductions or increases in price and quantity, respectively, and applied these to the price and quantity of drugs in our sample that had not yet experienced any generic entry in the first year in which exclusivity ends; the resulting values were our estimates of the post-entry price and quantity. ${ }^{35}$ To obtain the effects of Paragraph IV challenges and settlements, we multiplied the estimated welfare effects by the differential probability of any generic entry associated with each (in other words, we computed the expected impact of challenges and settlements on welfare). We computed these using the annual estimate, and summing up over five years using the lagged estimates from Table 5. Additionally, we

\footnotetext{
${ }^{34}$ Under these assumptions, the changes in consumer surplus, producer surplus and deadweight loss associated with generic entry are:

$$
\begin{gathered}
\Delta C S=\left(P^{m}-P^{c}\right) Q^{m}+\frac{1}{2}\left(\left(P^{m}-P^{c}\right)\left(Q^{m}-Q^{c}\right)\right) \\
\Delta P S=-\left(P^{m}-P^{c}\right) Q^{m} \\
\Delta D W L=-\frac{1}{2}\left(\left(P^{m}-P^{c}\right)\left(Q^{c}-Q^{m}\right)\right)
\end{gathered}
$$

where $P^{m}$ and $P^{c}$ and $Q^{m}$ and $Q^{c}$ refer to the pre-entry and post-entry price and quantity, respectively.

${ }^{35}$ We focused on the year in which exclusivity ends because that is point at which Paragraph IV challenges become most likely. We focused on drugs that had not yet had generic entry because we need a baseline from which to estimate the price and quantity changes from branded to generic.
} 
computed estimates overall and only for "large" drugs in the top quintile of potential market, because these are more likely to both be challenged and to settle (Table 2).

We report the results of this simulation in Table 7. The table reports the expected change in consumer surplus, producer surplus and deadweight loss in millions of 2011 dollars associated with a Paragraph IV challenge with and without settlement, and the difference. The impact of a Paragraph IV challenge with no settlement on consumer surplus is large and positive. We estimate that the challenge increases consumer surplus by approximately $\$ 537$ million. Settling the challenge reduces this gain in surplus by $\$ 470$ million, and if we extend the analysis over five years it results in a reduction in consumer surplus of $\$ 835$ million. A significant portion of the reduction in consumer surplus is due to higher producer surplus. Settlements increase producer surplus by about $\$ 308$ million over five years, about 37\% of the total change. The remainder of the change (\$527 million) is due to higher deadweight loss. These effects are even larger if we focus on large drugs. For drugs in the top quintile of potential market, settling Paragraph IV challenges reduces consumer surplus by about $\$ 2.2$ billion over five years, with $\$ 815$ million due to higher producer surplus and $\$ 1.4$ billion due to additional deadweight loss.

The results suggest that the welfare implications of settling Paragraph IV challenges could be significant. Lanthier et al. (2013) report that from 1987 to 2011 there were 645 new drugs approved for the US market, about 26.9 per year, and that this has stayed relatively stable over time. Given that $6 \%$ of the drugs in our sample ever have a settlement on a Paragraph IV challenge, this means that we would expect roughly 40 settlements in Paragraph IV cases (this may be conservative given the upward trend in challenges over our sample). Using the deadweight loss estimates reported in Table 7, this suggests we would expect about \$21 billion in deadweight loss over the next 25 years due to settlements in Paragraph IV challenges. 
One point to note about our welfare calculations is that our large estimates of deadweight loss are driven by the estimated impact of generic entry on quantity sold. Our effects are larger than those found in some past work. For example, Lakdawalla and Sood (2013) found that insurance mitigates the impact of monopoly pricing on quantity, so that patent expiration was associated with relatively little impact on quantity sold in those markets. Lakdawalla and Philipson (2012) also find little increase in quantity after patent expiration for brand drugs because of a postexpiration decline in marketing. Our effect on quantity is larger in part because we focus on actual generic entry, which is not necessarily the same as patent expiration (due to evergreening, slow generic entry, etc.). Nevertheless, if you were to significantly reduce the estimated impact of entry on quantity, then our deadweight loss estimates would shrink and the welfare implications of settling Paragraph IV challenges would be simply to transfer consumer surplus to manufacturers in the form of higher profits.

\section{The Impact Of Allowing SetTlements in PARAgRAPH IV Challenges on Pharmaceutical ResearCH AND DeVelopMent}

Our findings indicate that allowing branded manufacturers to settle Paragraph IV challenges is associated with a significant delay in generic entry, beyond the 6 month duopoly period. This appears to lead to medium-term reductions in consumer surplus, while manufacturer profits and deadweight losses accrue. On the surface, this would seem to indicate that these settlements lower social welfare. However, this is true of patents in general, but society grants patent rights because these rights are associated with higher innovation that provides long-term social benefits. If the reductions in manufacturer profits were associated with a significant decline in investment in new pharmaceutical profits, this could lead to a net reduction in social welfare. 
Here we explore the impact of allowing settlement in Paragraph IV challenges on the incentives of branded manufacturers to invest in research and development (R\&D). Specifically if settlements delay entry and increase incumbents profits by allowing firms to delay generic entry then we should see an increase in $R \& D$ as firms now potentially have a higher return on $R \& D$ investment. To estimate this effect we collected data on R\&D expenditures on all companies in Compustat North American which list their primary NAICS as 3245 (pharmaceutical and medicine manufacturing). In particular, we used annual data on Compustat item 46, which measures company funded R\&D and excludes government funded R\&D. We also collected Compustat data on employment, the current value of assets, the book value of the company per share and the reported value of plants and equipment. The controls are designed to capture the ease with which the firm can finance R\&D by controlling for firm size and value (we based our specification on Hall et al., 2005, who describe these control variables in more detail).

In addition, we include whether the firms' headquarters (defined by Compustat) are located within a circuit has deemed settlements legal and the number of patents the firms have across all their drugs listed in the Orange book (i.e., we construct a measure of their patent count). We control for patent count because an increased number of patents provide a greater incentive to invest in R\&D given the security of any monopoly rents associated with that research. Descriptive statistics for these variables are provided in Table 8 .

We estimate manufacturer-year level regressions of the impact of allowing manufacturers to settle Paragraph IV challenges, using first differences to control for any autocorrelation. Specifically, we estimated the following empirical model:

$$
\Delta \ln \left(R D_{i t}\right)=\beta \Delta \text { patent }_{i t}+\beta \Delta \text { patent }_{i t-1}+\beta \Delta \text { patent }_{i t-2}+\beta \Delta \text { patent }_{i t-3}
$$




$$
\begin{gathered}
+\beta \Delta \text { patent }_{i t} \text { settle }_{i t}+\beta \Delta \text { patent }_{i t-1} \Delta \text { settle }_{i t-1}+\beta \Delta \text { patent }_{i t-2} \Delta \text { settle }_{i t-2} \\
+\beta \Delta \text { patent }_{i t-3} \Delta \text { settle }_{i t-3}+\delta \Delta X_{i t}+\epsilon_{i t}
\end{gathered}
$$

Here, patent $_{i t}$ is the patent count for company $\mathrm{i}$ in year $\mathrm{t}$, settle is equal to one if the company is headquartered in a circuit allowing unchallenged settlements following the circuits' ruling, $X$ are the above mentioned control variables. Note that we interact the patent count with the indicator variable for companies headquartered in circuits which deemed settlements legal to allow for the fact that a higher patent count makes the impact of settlement more important. In addition we lag the patent count and interaction terms by one to three years to account for the fact that R\&D decisions may not adjust immediately after the circuit court ruling.

The results of these regressions are reported in Table 9. When the model is estimated without lags we find that companies headquartered in circuits allowing for unreviewed settlements have higher R\&D spending although the effect is not statistically significant. In Column 2 we estimate the model with lagged patent count and lagged patent count settlement interaction. We find that R\&D spending is approximately $0.06 \%$ percent higher for each patent in the period 1 year after the ruling. The impact per patent is approximately $\$ 139,000$ per year $(0.06 \%$ of $\$ 232$ million). Thus for a firm with our average of 9 active patents in a given year this translates into approximately $\$ 1.29$ million in increased R\&D spending or about one-half of one percent of the annual R\&D budget for an average firm. In the second year after the ruling the number increases by $0.035 \%$ in addition to the $0.06 \%$, resulting in another $\$ 559,500$ per year for our typical firm and bringing the total impact in year $0.09 \%$ of the R\&D budget. Column 3 we find no further upward shifts in impact in year 3, suggesting the full impact is observed in the first two years.

These findings seem to suggest that limiting settlements in Paragraph IV challenges is associated with lower R\&D investments by firms. The magnitude of this effect is small, but seems 
comparable to some past studies. Finkelstein (2004) finds that a $\$ 1$ reduction in market size is associated with a 6 cent reduction in investment in clinical trials in new vaccines, suggesting an elasticity of investment of 0.06 . We find that settling Paragraph IV challenges increases manufacturer profits by approximately $\$ 331$ million. Given that approximately $6 \%$ of drugs in our sample ever settle a Paragraph IV challenge, this means that settlements increase expected revenue by about $\$ 18.4$ million on average. Applying Finkelstein's elasticity and recognizing that each manufacturer has 9 patents on average, this would be associated with a reduction in $R \& D$ spending of about $\$ 9.9$ million or $4.3 \%$ of the total budget. The much smaller effect that we find could be due to the split in the circuit court rulings, so manufacturers anticipated that eventually the split could be resolved by legislation or the Supreme Court and settlements might not be allowed.

We can use the findings of Lanthier et al. (2013) to consider the how the welfare effects of lower innovation compare to the estimated market effects discussed above. If eliminating settlements in Paragraph IV challenges decreased investment by just $0.09 \%$ it would mean approximately 0.6 fewer drugs over the next 25 years. To fully offset the estimated $\$ 21$ billion in deadweight loss caused by settlements, the expected value of a drug would need to be $\$ 35$ billion. That might be feasible for a truly innovative, first-in-class drug, but according to Lanthier et al. (2013) that is a relatively small share of all drugs (less than a third). However, if we take the effect implied by Finkelstein's elasticity estimate, we would expect closer to 28 fewer drugs over the next 25 years. This would imply that the typical drug would only need to generate approximately $\$ 750$ million in value to offset the welfare loss associated with settlements. This is probably much closer to the value of a typical drug. 


\section{DISCUSSION AND CONCLUSION}

We estimate the impact of Paragraph IV challenges and reverse settlements on pharmaceutical market outcomes. Using a quasi-experiment created by the Circuit spilt over the legality of FTC review of reverse settlements combined with information on patent strength and the timing of challenges, we find that Paragraph IV challenges increase the likelihood of entry but that settlements largely undo that effect. Moreover, we find that these effects persist over time, suggesting that settlements inflate price and depress quality for up to 5 years after the initial challenge. The deadweight loss from a settlement is approximately \$527 million per challenge. Our simulated welfare effects suggest that over the next 25 years we might expect $\$ 21$ billion in deadweight loss attributable to settlements in Paragraph IV challenges, and this estimate is likely conservative because the number of challenges and settlements has been increasing over time.

We also estimate the impact of Paragraph IV challenges and settlements on the level of innovation for pharmaceuticals. We use the location of branded drug manufacturers' corporate headquarters to study the effect of the Circuit split on their investments in research and development. We find that R\&D spending fell as a result of the decision, but only by about $0.09 \%$ of total spending. Part of the small magnitude could reflect manufacturer uncertainty about the legality of future settlements. If we apply estimates from the literature, the expected decline in profits from eliminating settlements could reduce R\&D spending by as much as $4.6 \%$. If this were to occur, we could see as many as 31 fewer drugs over the next 25 years, which could offset most or all of the welfare gains to consumers.

These results have important implications for the current debates over whether reverse settlements should be allowed. In practice much of the loss in consumer surplus which results from allowing settlements represents a transfer to producers and not a deadweight loss. Moreover this 
transfer has a small impact on research and development and hence future innovation. As such our results are consistent with the Supreme Court's 2013 ruling in FTC vs. Actavis, which reversed the Eleventh Circuit's ruling that the FTC could not pursue antitrust actions in reverse settlement cases. The Eleventh Circuit had ruled that antitrust law did not apply to patent cases because the reverse payment would not restrict competition more than the original patent. The Supreme Court further stipulated that settlements were not per se illegal but would be evaluated by a rule of reason balancing test. Going forwards, this means that settlements must be evaluated on a case-by-case basis to determine if the benefits of settlement outweigh any anti-competitive effects. Our findings suggest that on average the anti-competitive effects may be large, but the courts should consider not just the short-term implications for consumers but also incorporate the potential long-term impact on innovation. While courts have generally not been sympathetic to the argument that anticompetitive behavior could be justified by increases in innovation in the context of patents innovation would almost certainly have to be included in any calculus of the benefits of settlement in patent litigation cases.

While our results cannot determine if all settlements are indeed collusive, they do suggest that settlements operate in much the same way as patents because they deter entry and inflate price and depress quantity. However, in an effort to improve matters for today's consumers, it is important to ensure that the benefits of lowering price and increasing quantity today would not be more than offset by the potential loss of innovative new drugs. Our estimates suggest that this is unlikely to be the case unless manufacturers are highly responsive to relatively small changes in expected profit in terms of their R\&D decisions, or if the potential value of new drugs is high.

It is worth highlighting that our estimates of the impact of relied heavily on the Finkelstein (2004) estimate of the elasticity of R\&D investments with respect to profitability, which is on the 
conservative side in the literature. For example, Acemoglu and Lin (2004) find a much bigger relationship, suggesting an elasticity of 4 to 6 in terms of potential market and the number of new drugs. Bloom-Kohout and Sood (2012) and Yin (2008) examined the impact that the introduction of Medicare Part D and the Orphan Drug Act, respectively, had on the number of new drugs and similarly found a dramatic increase. While the large effects appear to be somewhat temporary, if we were to use these larger estimates of an R\&D response to changes in expected profitability, then we would expect a much larger impact on the number of new drugs. If this were the case, the short-term consumer welfare losses we estimate would probably not be large enough to offset the welfare costs of fewer new drugs.

It is also important to note that our welfare results could understate the costs of restricting settlements if the decline in revenue and exclusivity changed the behavior of manufacturers in other ways that lessened consumer surplus. For example, if companies market their products less (as found by Lakdawalla and Philipson, 2012), this could lead to depressed demand or less information (e.g., about side effects). It could also reduce the incentives of generic manufacturers to enter, restricting supply even after patent expiry. A lack of sufficient competition among generic manufacturers has been blamed as a possible source of the large recent price increases in generic drugs (Bryant, 2015).

Future work should seek to refine these estimates to better understand the conditions under which the net welfare effects of settlements are positive or negative. For example, it is possible that it would be welfare enhancing to allow settlements for more novel, first-in-class drugs is welfare enhancing while eliminating them for follow-up products. Policymakers, regulators and the courts need to carefully consider how to balance the short-term and medium-term interests of today's consumers versus the long-term societal interests. 


\section{REFERENCES}

Acemoglu, Daron \& Joshua Linn, (2004). "Market Size in Innovation: Theory and Evidence from the Pharmaceutical Industry," The Quarterly Journal of Economics, vol. 119(3), pages 1049-1090, August.

Angrist, Joshua D. (2001) "Estimation of Limited Dependent Variable Models with Dummy Endogenous Regressors." Journal of Business \& Economic Statistics 19(1):2-28.

Berndt, E. R., M. K. Kyle, and D. Ling (2003): “The long shadow of patent expiration: generic entry and RX-OTC switches," in Scanner data and price indexes, University of Chicago Press.

Berndt, Ernst R., Richard Mortimer, Ashoke Bhattacharjya, Andrew Parece, and Edward Tuttle. "Authorized generic drugs, price competition, and consumers' welfare." Health Affairs 26, no. 3 (2007): 790-799.

Blume-Kohout, Margaret E., and Neeraj Sood. "Market size and innovation: Effects of Medicare Part D on pharmaceutical research and development." Journal of public economics 97 (2013): 327336.

Bokhari, Farasat AS. "What Is the Price of Pay-to-Delay Deals?." Journal of Competition Law and Economics 9, no. 3 (2013): 739-753.

Bound, John, David A. Jaeger, Regina Baker (1995) "Problems with Instrumental Variables Estimation when the Correlation Between the Instruments and the Endogenous Explanatory Variables is Weak," Journal of the American Statistical Association, 90 (June): 443-450. 1995

Branstetter, Lee G., Chirantan Chatterjee \& Matthew Higgins, (2011) "Regulation and Welfare: Evidence from Paragraph IV Generic Entry in the Pharmaceutical Industry," NBER Working Papers 17188.

Furlow, Bryant. "Public outcry over US generic drug price hikes." The Lancet Respiratory Medicine 3.11 (2015): 840.

Bulow, J. (2004) "The Gaming of Pharmaceutical Patents," in Innovation Policy And The Economy 145, 159-73 (Adam B. Jaffe et al. eds.)

Caves, R. E., M. D. Whinston, M. A. Hurwitz, A. Pakes, and P. Temin (1991): "Patent expiration, entry, and competition in the U.S. pharmaceutical industry," Brookings Papers on Economic Activity, 1-66.

Drake, K. M., Starr, M. A., \& McGuire, T. (2014). Do" Reverse Payment" Settlements of BrandGeneric Patent Disputes in the Pharmaceutical Industry Constitute an Anticompetitive Pay for Delay? (No. w20292). National Bureau of Economic Research. 
Dorsney, Kenneth (2012) ANDA Litigation: Strategies and Tactics for Pharmaceutical Patent Litigators, American Bar Association.

Edlin, A. S., Hemphill, C. S., Hovenkamp, H. J., \& Shapiro, C. (2013). Activating Actavis.

Antitrust Magazine, Fall.

Edlin, Aaron S. and Hemphill, C. Scott and Hovenkamp, Herbert J. and Shapiro, Carl, The Actavis Inference: Theory and Practice (February 5, 2015). Columbia Public Law Research Paper No. 14459. Available at SSRN: http://ssrn.com/abstract $=2560107$ or http://dx.doi.org/10.2139/ssrn.2560107

Federal Trade Commission. Pay-for-delay: how drug company pay-offs cost consumers billions. January 2010. (http://www.ftc.gov/os/2010/01/100112payfordelayrpt.pdf.)

Filson, Darren \& Oweis, Ahmed, 2010. "The impacts of the rise of Paragraph IV challenges on startup alliance formation and firm value in the pharmaceutical industry," Journal of Health Economics, Elsevier, vol. 29(4), pages 575-584, July.

Finkelstein, Amy. "Static and dynamic effects of health policy: Evidence from the vaccine industry." Quarterly Journal of Economics 119.2 (2004): 527-564.

Goldman DP, Joyce GF, Escarce JJ, et al. Pharmacy benefits and the use of drugs by the chronically ill. JAMA. May 19 2004;291(19):2344-2350.

Goldman DP, Joyce GF, Karaca-Mandic P. (2006a) Varying pharmacy benefits with clinical status: the case of cholesterol-lowering therapy. American Journal of Managed Care. 12(1): 21-28.

Goldman DP, Joyce GF, Lawless G, Crown WH, Willey V. (2006b) Benefit design and specialty drug use. Health Affairs. 25(5):1319-1331.

Goldman DP, Joyce GF, Zheng Y. Prescription drug cost sharing: associations with medication and medical utilization and spending and health. JAMA. Jul 4 2007;298(1):61-69.

Goldman, Dana P., Darius N. Lakdawalla, Jesse D. Malkin, John Romley, and Tomas Philipson. "The benefits from giving makers of conventional 'small molecule' drugs longer exclusivity over clinical trial data." Health Affairs 30, no. 1 (2011): 84-90.

Grabowski, Henry G., and John M. Vernon. "Returns to R\&D on new drug introductions in the 1980s." Journal of Health Economics 13.4 (1994): 383-406.

Grabowski, Henry. "Are the economics of pharmaceutical research and development changing?." Pharmacoeconomics 22.2 (2004): 15-24.

Grabowski, Henry G., and Margaret Kyle. 2007. "Generic Competition and Market Exclusivity Periods in Pharmaceuticals.” Managerial and Decision Economics vol. 28, 491-502. 
Hall, Bronwyn H., Adam Jaffe and Manuel Trajtenberg "Market Value and Patent Citations" RAND Journal of Economics Vol. 36, No. 1 (Spring, 2005), pp. 16-38

Hemphill, Scott (2006) "Paying for Delay: Pharmaceutical Patent Settlement as a Regulatory Design Problem", New York University Law Review 81:1553

Hemphill, C. Scott, (2007) “ Drug Patent Settlements Between Rivals: A Survey” Available at SSRN: http://ssrn.com/abstract=969492 or http://dx.doi.org/10.2139/ssrn.969492

Hemphill, Scott and Bhaven Sampat (2011) "When Do Generics Challenge Drug Patents?" Journal of Empirical Legal Studies 613.

Hemphill, C. Scott, and Bhaven N. Sampat. "Evergreening, patent challenges, and effective market life in pharmaceuticals." Journal of Health Economics 31.2 (2012): 327-339.

Higgins, Matthew J., and Stuart JH Graham. "Balancing innovation and access: patent challenges tip the scales." Science 326, no. 5951 (2009): 370-371.

Howard DH, Bach PB, Berndt ER, Conti RM. "Pricing in the Market for Anticancer Drugs." The Journal of Economic Perspectives. 2015 Feb 1;29(1):139-62.

Huskamp, H. A., J. M. Donohue, C. Koss, E. R. Berndt, and R. G. Frank (2008): “Generic Entry, Reformulations, and Promotion of SSRIs," Pharmacoeconomics, 7, 603-616.

Joyce GF, Escarce JJ, Solomon MD, Goldman DP. Employer drug benefit plans and spending on prescription drugs. JAMA. Oct 9 2002;288(14):1733-1739.

Jaffe, A. and M. Trajtenberg (eds.) Patents, Citations and Innovations. Cambridge, MA: The MIT Press, 2002.

Kesselheim, Aaron S., Lindsey Murtagh, and Michelle M. Mello. "“Pay for Delay" Settlements of Disputes over Pharmaceutical Patents." New England Journal of Medicine 365.15 (2011): 14391445.

Lanjouw, Jean O. and Mark Schankerman (2001) "Characteristics of Patent Litigation: A Window on Competition," RAND Journal of Economics, Vol. 32, No. 1, pp. 129-151

Lakdawalla, Darius, and Tomas Philipson. "Does Intellectual Property Restrict Output? An Analysis of Pharmaceutical Markets." Journal of Law and Economics 55, no. 1 (2012): 151-187.

Lakdawalla, Darius, and Neeraj Sood. "Health insurance as a two-part pricing contract." Journal of public economics 102 (2013): 1-12.

Lanthier, M., Miller, K. L., Nardinelli, C., \& Woodcock, J. (2013). An improved approach to measuring drug innovation finds steady rates of first-in-class pharmaceuticals, 1987-2011. Health Affairs, 32(8), 1433-1439. 
Lichtenberg, F. R. and G. Duflos (2009): "Time Release: The Effect of Patent Expiration on U.S. Drug Prices, Marketing, and Utilization by the Public," Manhattan Institute Medical Progress Report, 11.

Miceli, Thomas J. "Economics of the law: Torts, contracts, property, litigation." (1997). National Academy of Sciences.

Panattoni, Laura E. "The effect of Paragraph IV decisions and generic entry before patent expiration on brand pharmaceutical firms." Journal of health economics 30, no. 1 (2011): 126-145.

Reiffen, D., Ward, M., 2005. Generic drug industry dynamics. Review of Economics and Statistics. $87,37-49$.

Saha, A., Grabowski, H., Birnbaum, H., Greenberg, P., Bizen, O., 2006. Generic competition in the US pharmaceutical industry. International Journal of the Economics of Business. 13, 15-38.

Shapiro, Carl (2003) “Antitrust Limits to Patent Settlements," RAND Journal of Economics Vol. 34, No. 2, pp. 391-411

Scherer, F.M., 2001. The link between gross profitability and pharmaceutical R\&D spending. Health Affairs. 20, 216-220.

Spier, Kathryn E. "Litigation." Handbook of law and economics 1 (2007): 259-342.

Staiger, D. and J.H. Stock (1997): "Instrumental Variables Regression with Weak Instruments," Econometrica, 65, 557 - 586.

Tefferi A, Kantarjian H, Rajkumar SV, et al. "In support of a patient-driven initiative and petition to lower the high price of cancer drugs." Mayo Clinic Proceedings. 2015.

Wooldridge Jeffrey, M. (2002) Econometric Analysis of Cross Section and Panel Data.

Yin W. Market incentives and pharmaceutical innovation. Journal of Health Economics. 2008;27(4):1060-77. 
Figure 1: Trend in Paragraph IV Challenges

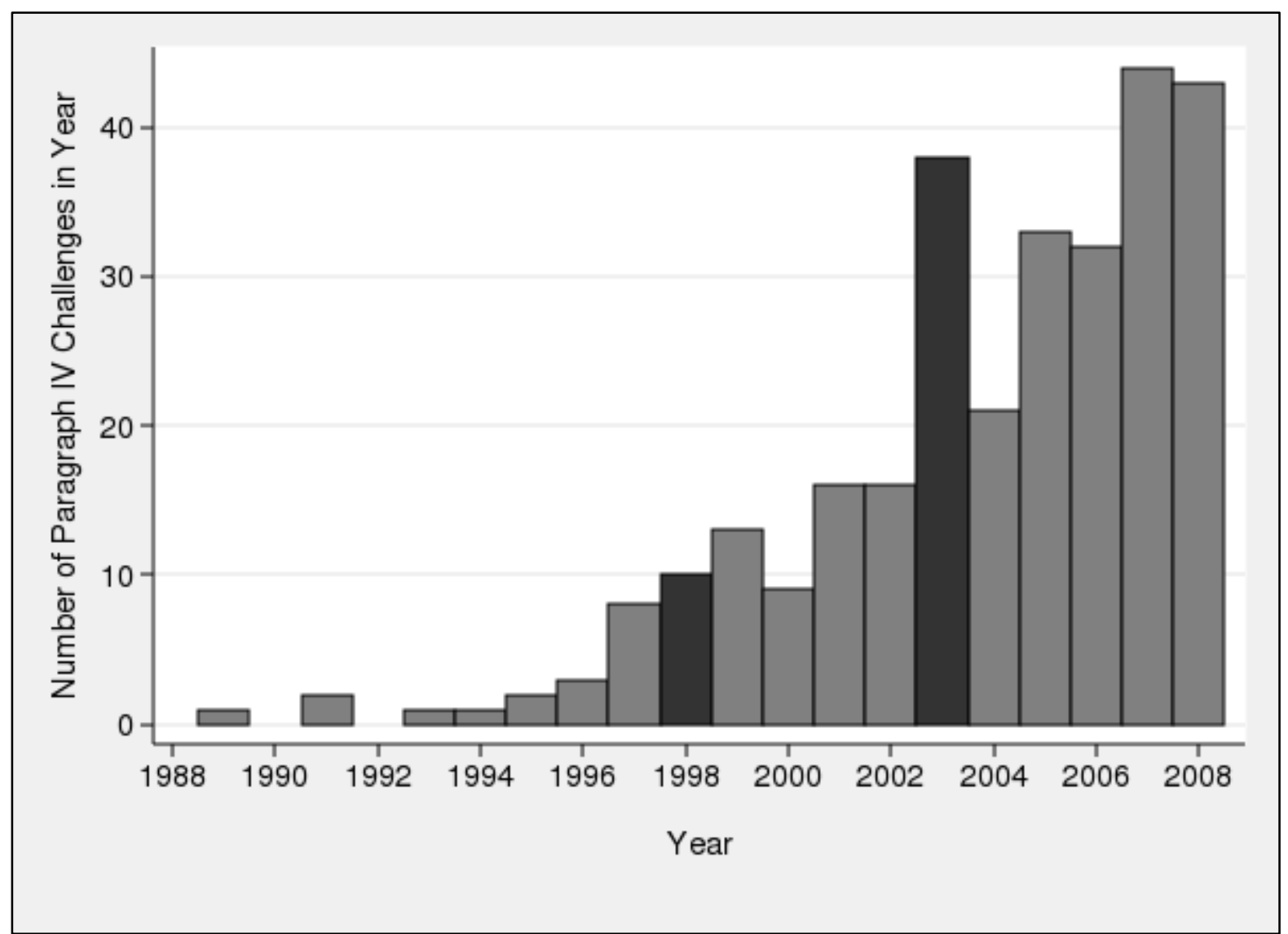

Notes: Figure reports the number of Paragraph IV challenges by year from 1989 through 2008. Data are reported by the FDA (see Barnstetter et al., 2011). 
Figure 2. Percent of Paragraph IV Challenges that Settle by Year and Circuit

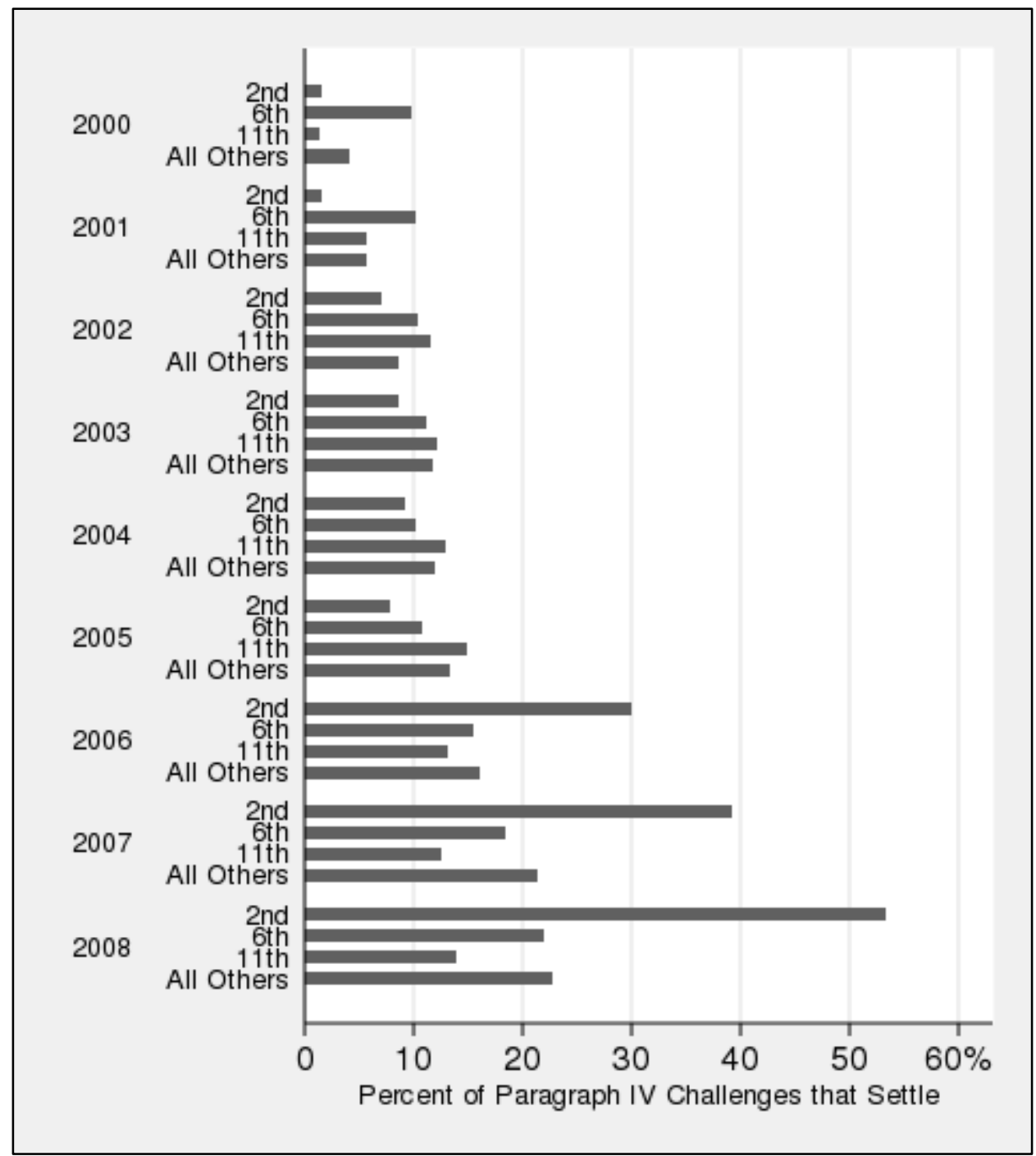

Notes: Figure reports the percent of all settlements by year according to the circuit court in which the pharmaceutical patent holder's corporate headquarters are located in, by year from 2000-2008. 
Figure 3. Percent of Drugs Facing a Paragraph IV Challenge in the Year by Strength of Patent

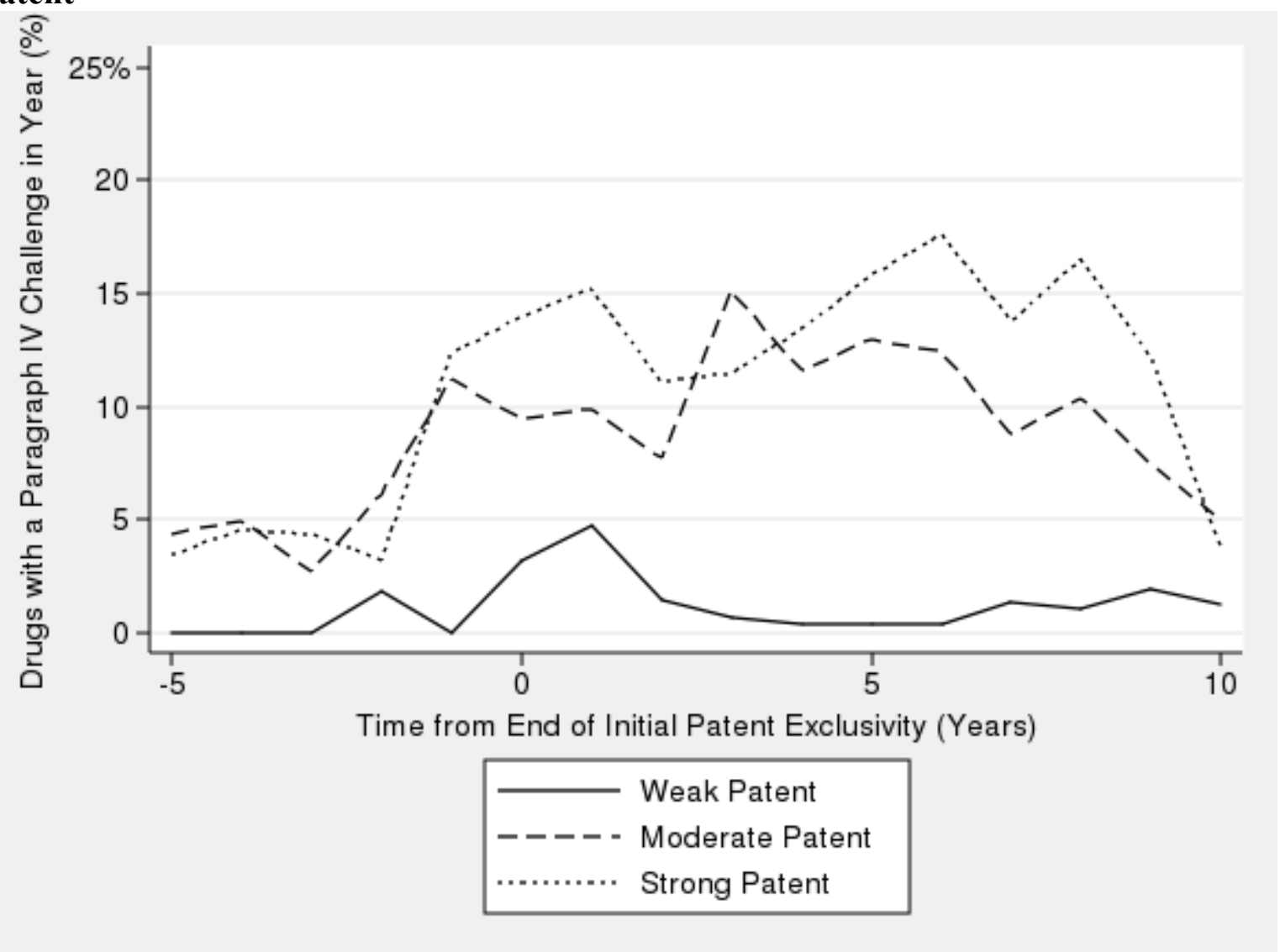

Notes: Figure reports the percent of drugs facing a Paragraph IV challenge by year from the end of the exclusivity period on the initial patent according to patent strength. Patent strength is broken into three categories based on the adjusted number of citations (that is, citations relative to other patients in the same cohort): weak patents have zero citations, moderate patents have less than the median citations conditional on at least one (approximately 0.7 ) and strong patents have greater than or equal to the conditional median number of citations. 
Figure 4: Percent of Drugs with Generic Entry with and without Settlement by Time from Exclusivity End

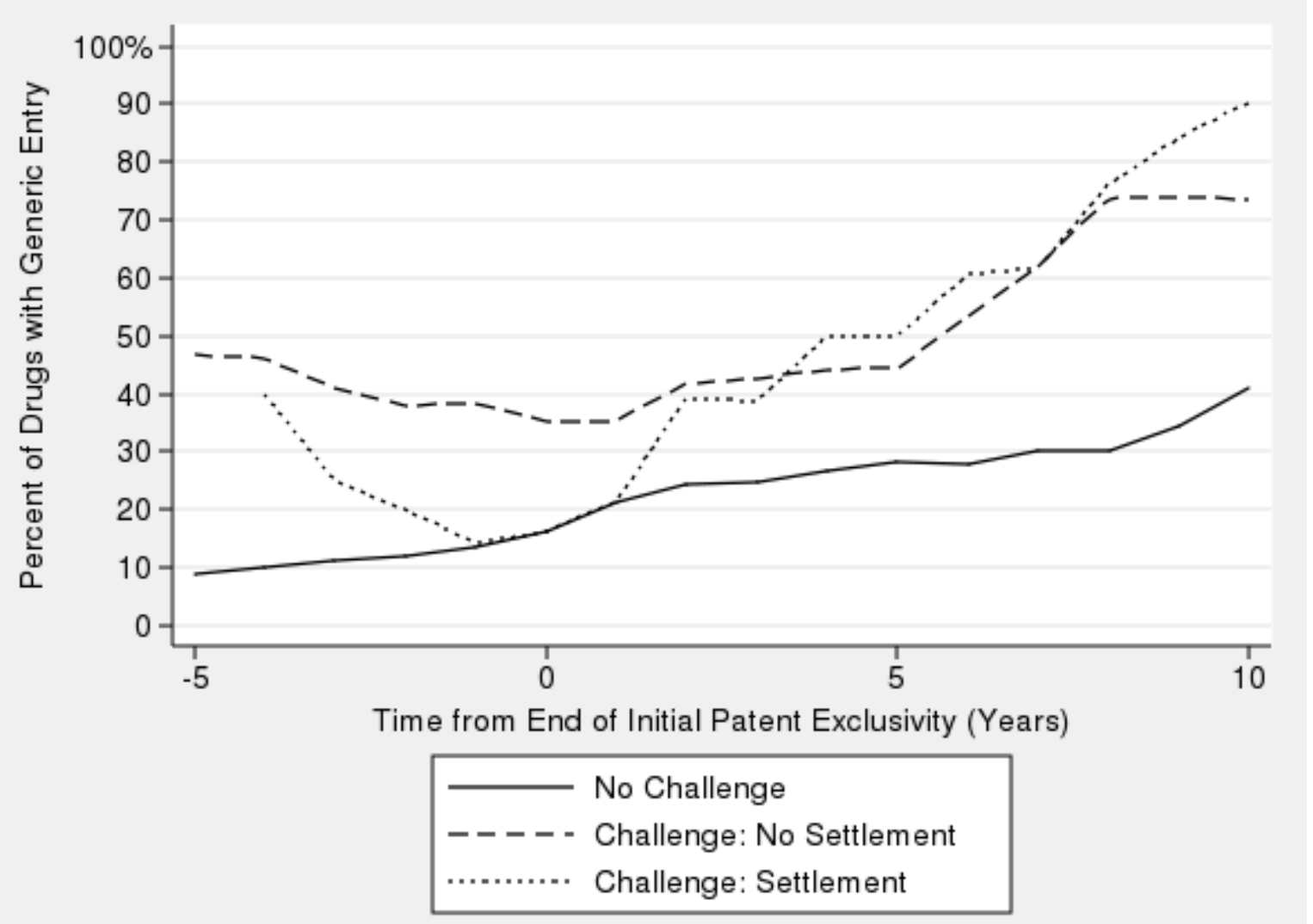

Notes: Figure reports the percent of drugs with at least one generic entrant by year from the end of the exclusivity period on the initial patent for drugs with no Paragraph IV challenge, drugs with a Paragraph IV challenge that don't settle, and for drugs with a Paragraph IV channel that do settle. 
Table 1. Summary Statistics

\begin{tabular}{|c|c|c|c|c|}
\hline & Full Sample & $\begin{array}{c}\text { Patent Challenge: } \\
\text { No Settlement }\end{array}$ & $\begin{array}{c}\text { Patent Challenge: } \\
\text { Settlement }\end{array}$ & No Challenge \\
\hline & Mean (S.D.) & Mean (S.D.) & Mean (S.D.) & Mean (S.D.) \\
\hline Number of Prescription & $\begin{array}{c}2,977,463 \\
(8,951,992)\end{array}$ & $\begin{array}{c}5,718,418 \\
(12,055,942)\end{array}$ & $\begin{array}{c}10,328,757 \\
(16,442,230)\end{array}$ & $\begin{array}{c}992,328 \\
(4,310,438)\end{array}$ \\
\hline Price per Prescription & $512(2,643)$ & $505(3,546)$ & $346(1,657)$ & $533(2,213)$ \\
\hline Any Generic Entry & $0.25(0.43)$ & $0.35(0.48)$ & $0.38(0.48)$ & $0.19(0.40)$ \\
\hline Number of Entrants & $3.31(4.76)$ & $4.36(6.07)$ & $5.82(7.40)$ & $2.58(3.38)$ \\
\hline Patent Challenge & $0.21(0.41)$ & $0.58(0.49)$ & $0.63(0.48)$ & $0.00(0.00)$ \\
\hline Settlement & $0.04(0.20)$ & $0.00(0.00)$ & $0.61(0.49)$ & $0.00(0.00)$ \\
\hline Settlements Allowed & $0.01(0.09)$ & $0.01(0.11)$ & $0.09(0.28)$ & $0.00(0.00)$ \\
\hline Number of Patent Citations & $-5.36(6.34)$ & $-3.08(6.00)$ & $-2.75(4.69)$ & $-6.65(6.26)$ \\
\hline Time Until End of Exclusivity & $0.56(0.93)$ & $0.85(1.01)$ & $1.07(1.17)$ & $0.38(0.81)$ \\
\hline Cites*Time Until End of Exclusivity & $-1.95(7.29)$ & $-1.86(9.87)$ & $-2.65(6.17)$ & $-1.92(5.88)$ \\
\hline Potential Market & $18.11(2.02)$ & $18.71(1.61)$ & $19.14(1.11)$ & $17.71(2.16)$ \\
\hline Number of Other Drugs in Class & $19.37(23.79)$ & $25.01(29.01)$ & $20.42(26.07)$ & $16.72(20.22)$ \\
\hline \multicolumn{5}{|l|}{ Warning Label Indicators: } \\
\hline Contraindications & $0.01(0.08)$ & $0.01(0.11)$ & $0.03(0.18)$ & $0.00(0.04)$ \\
\hline Warnings & $0.28(0.45)$ & $0.42(0.49)$ & $0.38(0.49)$ & $0.20(0.40)$ \\
\hline Precautions & $0.48(0.50)$ & $0.63(0.48)$ & $0.69(0.46)$ & $0.39(0.49)$ \\
\hline Adverse Reactions & $0.36(0.48)$ & $0.54(0.50)$ & $0.62(0.49)$ & $0.25(0.43)$ \\
\hline Medication Guide & $0.03(0.16)$ & $0.04(0.20)$ & $0.05(0.23)$ & $0.02(0.13)$ \\
\hline Patient Package Insert & $0.06(0.23)$ & $0.11(0.31)$ & $0.10(0.31)$ & $0.03(0.17)$ \\
\hline Dosage and Administration & $0.19(0.39)$ & $0.29(0.46)$ & $0.28(0.45)$ & $0.13(0.34)$ \\
\hline Clinical Pharmacology & $0.17(0.38)$ & $0.30(0.46)$ & $0.28(0.45)$ & $0.11(0.31)$ \\
\hline Indications and Usage & $0.19(0.39)$ & $0.34(0.47)$ & $0.29(0.45)$ & $0.11(0.32)$ \\
\hline Overdose & $0.10(0.29)$ & $0.12(0.33)$ & $0.18(0.38)$ & $0.07(0.26)$ \\
\hline Dependence & $0.01(0.09)$ & $0.01(0.11)$ & $0.01(0.12)$ & $0.01(0.08)$ \\
\hline References & $0.02(0.15)$ & $0.01(0.10)$ & $0.04(0.19)$ & $0.03(0.16)$ \\
\hline Clinical Studies & $0.02(0.13)$ & $0.03(0.18)$ & $0.03(0.17)$ & $0.01(0.09)$ \\
\hline Description & $0.03(0.17)$ & $0.04(0.20)$ & $0.04(0.21)$ & $0.02(0.15)$ \\
\hline How Supplied & $0.03(0.18)$ & $0.05(0.23)$ & $0.06(0.24)$ & $0.02(0.15)$ \\
\hline Miscellaneous & $0.17(0.38)$ & $0.27(0.45)$ & $0.19(0.39)$ & $0.12(0.33)$ \\
\hline Boxed Warning & $0.08(0.26)$ & $0.11(0.31)$ & $0.07(0.25)$ & $0.06(0.24)$ \\
\hline \multicolumn{5}{|l|}{ Adverse Event Counts: } \\
\hline Congenital Anomaly & $0.51(2.68)$ & $0.95(3.91)$ & $0.83(2.19)$ & $0.28(1.89)$ \\
\hline Death & $10.45(65.66)$ & $20.87(104.55)$ & $23.63(108.71)$ & $4.41(21.44)$ \\
\hline Disability & $3.38(28.09)$ & $6.44(44.98)$ & $7.86(19.93)$ & $1.55(16.20)$ \\
\hline Hospitalization & $27.52(93.17)$ & $50.82(138.91)$ & $57.72(90.23)$ & $13.93(58.51)$ \\
\hline Life Threatening & $3.45(12.05)$ & $6.10(14.50)$ & $6.43(9.93)$ & $1.95(10.68)$ \\
\hline Required Intervention & $40.71(198.10)$ & $78.46(293.38)$ & $95.29(226.07)$ & $18.12(124.35)$ \\
\hline Other & $4.58(27.99)$ & $8.93(47.53)$ & $9.52(28.84)$ & $2.12(9.79)$ \\
\hline Observations & 9,648 & 2,804 & 632 & 6,212 \\
\hline
\end{tabular}


Table 2. Rates of Challenge and Settlement by Potential Market and Exclusivity

\begin{tabular}{|c|c|c|c|c|c|}
\hline & \multicolumn{5}{|c|}{ Quintile of Potential Market for Drug } \\
\hline & $1^{\text {st }}$ & $2^{\text {nd }}$ & $3^{\text {rd }}$ & $4^{\text {th }}$ & $5^{\text {th }}$ \\
\hline \multicolumn{6}{|c|}{ Percent of Drugs with a Paragraph IV Challenge } \\
\hline All Years after Exclusivity End & $8.5 \%$ & $20.3 \%$ & $23.5 \%$ & $23.7 \%$ & $34.2 \%$ \\
\hline \multicolumn{6}{|c|}{ By Time from End of First Exclusivity Period } \\
\hline Prior to Exclusivity End Date & $6.9 \%$ & $9.2 \%$ & $14.5 \%$ & $15.8 \%$ & $22.0 \%$ \\
\hline 1 to 5 Years After Exclusivity Ends & $9.7 \%$ & $26.9 \%$ & $31.4 \%$ & $30.5 \%$ & $40.9 \%$ \\
\hline 5+ After Exclusivity Ends & $9.2 \%$ & $24.3 \%$ & $31.7 \%$ & $28.0 \%$ & $42.9 \%$ \\
\hline \multicolumn{6}{|c|}{ Percent of Drugs with a Paragraph IV Challenge that Settled } \\
\hline All Years after Exclusivity End & $4.2 \%$ & $9.1 \%$ & $24.4 \%$ & $20.8 \%$ & $25.7 \%$ \\
\hline $\begin{array}{l}\text { Notes: The top panel of the table rep } \\
\text { IV challenges by year from the end } \\
\text { percent of drugs in a year that faced } \\
\text { drugs that did not have a challenge }\end{array}$ & $\begin{array}{l}\text { ne perce } \\
\text { lusivity } \\
\text { raph IV }\end{array}$ & $\begin{array}{l}\text { f drugs } \\
\text { he first } \\
\text { llenges }\end{array}$ & $\begin{array}{l}\text { year tha } \\
\text { nt. The } \\
\text { also set }\end{array}$ & $\begin{array}{l}\text { ve faced } \\
\text { om pane } \\
\text { the chal }\end{array}$ & $\begin{array}{l}\text { agraph } \\
\text { ports the } \\
\text { e (so }\end{array}$ \\
\hline
\end{tabular}


Table 3. The Estimated First-stage Effects of Instruments on Paragraph IV Challenges and Settlements

\begin{tabular}{|c|c|c|c|c|}
\hline & (1) & (2) & (3) & (4) \\
\hline & \multicolumn{2}{|c|}{$\begin{array}{c}\text { Dependent Variable: } \\
\text { Paragraph IV Challenge }\end{array}$} & \multicolumn{2}{|c|}{$\frac{\text { Dependent Variable: }}{\text { Settlement }}$} \\
\hline $\begin{array}{l}\text { Time Until End of } \\
\text { Exclusivity }\end{array}$ & $\begin{array}{c}0.008^{* * * *} \\
(0.002)\end{array}$ & $\begin{array}{c}-0.022 * * * \\
(0.003)\end{array}$ & $\begin{array}{c}0.001 \\
(0.001)\end{array}$ & $\begin{array}{l}-0.004 \\
(0.003)\end{array}$ \\
\hline Settlements Allowed & $\begin{array}{c}0.495 * * * \\
(0.052)\end{array}$ & $\begin{array}{c}0.380 * * * \\
(0.052)\end{array}$ & $\begin{array}{c}0.440 * * * \\
(0.085)\end{array}$ & $\begin{array}{r}0.278^{* * *} \\
(0.0598)\end{array}$ \\
\hline Number of Patent Citations & $\begin{array}{l}0.012 * \\
(0.006)\end{array}$ & & $\begin{array}{c}0.010 \\
(0.006)\end{array}$ & \\
\hline $\begin{array}{l}\text { Cites*Time Until End of } \\
\text { Exclusivity }\end{array}$ & $\begin{array}{c}-0.009 * * * \\
(0.002)\end{array}$ & $\begin{array}{c}-0.008^{* * *} \\
(0.002)\end{array}$ & $\begin{array}{l}-0.001 \\
(0.001)\end{array}$ & $\begin{array}{r}-0.003 * * \\
(0.001)\end{array}$ \\
\hline F-Statistic for Instruments & 44.62 & 40.84 & 15.92 & 24.54 \\
\hline Fixed Effects & $\begin{array}{c}\text { Therapeutic } \\
\text { Class }\end{array}$ & Drug & $\begin{array}{l}\text { Therapeutic } \\
\text { Class }\end{array}$ & Drug \\
\hline
\end{tabular}

Notes: Table presents coefficients for the first stage regressions of Paragraph IV challenges and settlements. Each column represents a different linear probability regression. The dependent variable for Columns 1 and 2 is a binary variable that equals one for all years after the first Patent Challenge. The dependent variable for Columns 3 and 4 is a binary variable indicating the subset of drugs in which we identified a settlement. All estimates include warning label indicators, adverse event counts, the potential market proxy, the number of competitor molecules in the therapeutic class, the time remaining on exclusivity and year fixed effects. Robust standard errors adjusted to allow clustering at the therapeutic class level are reported in parentheses. A *,** or $* * *$ indicates statistical significance at the $10 \%, 5 \%$ and $1 \%$ levels, respectively. 
Table 4. The Estimated Impact of Paragraph IV Challenges and Settlements on Generic Entry

\begin{tabular}{|c|c|c|c|c|c|c|c|c|}
\hline & (1) & (2) & (3) & (4) & (5) & (6) & (7) & (8) \\
\hline & \multicolumn{4}{|c|}{$\frac{\text { Dependent variable: }}{\text { Any Generic Entry }}$} & \multicolumn{4}{|c|}{$\begin{array}{l}\text { Dependent variable: } \\
\text { Number of Entrants }\end{array}$} \\
\hline Paragraph IV Challenge & $\begin{array}{c}0.252 * * * \\
(0.037)\end{array}$ & $\begin{array}{l}0.100 * * * \\
(0.023)\end{array}$ & $\begin{array}{c}0.678 * * \\
(0.268)\end{array}$ & $\begin{array}{c}0.180 \\
(0.175)\end{array}$ & $\begin{array}{l}2.067 * * * \\
(0.417)\end{array}$ & $\begin{array}{l}0.540 * * \\
(0.257)\end{array}$ & $\begin{array}{c}9.838 * * * \\
(3.466)\end{array}$ & $\begin{array}{c}12.310 * * \\
(5.664)\end{array}$ \\
\hline Settlement & $\begin{array}{c}0.007 \\
(0.044)\end{array}$ & $\begin{array}{l}0.0533 \\
(0.062)\end{array}$ & $\begin{array}{l}-0.595 \\
(0.431)\end{array}$ & $\begin{array}{c}0.039 \\
(0.289)\end{array}$ & $\begin{array}{l}2.338 * * * \\
(0.853)\end{array}$ & $\begin{array}{l}1.186 \\
(0.729)\end{array}$ & $\begin{array}{c}-10.280 * \\
(5.891)\end{array}$ & $\begin{array}{l}-16.210 \\
(10.520)\end{array}$ \\
\hline $\begin{array}{l}\text { Combined Effect of } \\
\text { Challenge with Settlement }\end{array}$ & $\begin{array}{l}0.259 * * * \\
(0.037)\end{array}$ & $\begin{array}{c}0.154 * * \\
(0.059)\end{array}$ & $\begin{array}{c}0.083 \\
(0.241)\end{array}$ & $\begin{array}{c}0.219 \\
(0.136)\end{array}$ & $\begin{array}{l}4.405 * * * \\
(0.835)\end{array}$ & $\begin{array}{c}1.726^{* * *} \\
(0.650)\end{array}$ & $\begin{array}{l}-0.444 \\
(3.493)\end{array}$ & $\begin{array}{l}-3.900 \\
(5.497)\end{array}$ \\
\hline \multirow[t]{2}{*}{ Fixed Effects } & $\begin{array}{c}\text { Therapeutic } \\
\text { Class }\end{array}$ & Drug & $\begin{array}{c}\text { Therapeutic } \\
\text { Class }\end{array}$ & Drug & $\begin{array}{c}\text { Therapeutic } \\
\text { Class }\end{array}$ & Drug & $\begin{array}{c}\text { Therapeutic } \\
\text { Class }\end{array}$ & Drug \\
\hline & OLS & OLS & 2SLS & $2 \mathrm{SLS}$ & OLS & OLS & 2SLS & 2SLS \\
\hline
\end{tabular}

Notes: Table presents coefficients for the OLS and 2SLS regressions of Paragraph IV challenges and settlements on generic entry. The dependent variable for Columns 1-4 is an indicator for any generic entry at the molecule-year level, while the dependent variable for Columns 5-8 is a count of all entrants for the molecule-year. All estimates include warning label indicators, adverse event counts, the potential market proxy, the number of competitor molecules in the therapeutic class, the time remaining on exclusivity, therapeutic class and year fixed effects. Robust standard errors adjusted to allow clustering at the therapeutic class level are reported in parentheses. $\mathrm{A} * * *$ or $* * *$ indicates statistical significance at the $10 \%, 5 \%$ and $1 \%$ levels, respectively. 
Table 5. The Estimated Impact of Paragraph IV Challenges and Settlements on Generic Entry

\begin{tabular}{|c|c|c|c|c|}
\hline & (1) & (2) & (3) & (4) \\
\hline & \multicolumn{2}{|c|}{$\frac{\text { Dependent variable: }}{\text { Any Generic Entry }}$} & \multicolumn{2}{|c|}{$\frac{\text { Dependent variable: }}{\text { Number of Entrants }}$} \\
\hline & $\begin{array}{c}\text { Paragraph IV } \\
\text { Challenge with No } \\
\text { Settlement }\end{array}$ & $\begin{array}{c}\text { Paragraph IV } \\
\text { Challenge with } \\
\text { Settlement }\end{array}$ & $\begin{array}{c}\text { Paragraph IV } \\
\text { Challenge with No } \\
\text { Settlement }\end{array}$ & $\begin{array}{c}\text { Paragraph IV } \\
\text { Challenge with } \\
\text { Settlement }\end{array}$ \\
\hline Effect in Current Year & $\begin{array}{c}0.678^{* *} \\
(0.268)\end{array}$ & $\begin{array}{c}0.083 \\
(0.241)\end{array}$ & $\begin{array}{c}9.838 * * * \\
(3.466)\end{array}$ & $\begin{array}{c}-0.444 \\
(3.493)\end{array}$ \\
\hline \multicolumn{5}{|l|}{ Lagged effect: } \\
\hline 1 year lag & $\begin{array}{c}0.606 * * * \\
(0.232)\end{array}$ & $\begin{array}{c}0.112 \\
(0.267)\end{array}$ & $\begin{array}{c}8.854 * * * \\
(3.025)\end{array}$ & $\begin{array}{l}-0.421 \\
(3.866)\end{array}$ \\
\hline 2 year lag & $\begin{array}{c}0.584 * * * \\
(0.212)\end{array}$ & $\begin{array}{c}0.231 \\
(0.272)\end{array}$ & $\begin{array}{c}8.530 * * * \\
(2.813)\end{array}$ & $\begin{array}{c}0.836 \\
(4.097)\end{array}$ \\
\hline 3 year lag & $\begin{array}{l}0.612 * * * \\
(0.216)\end{array}$ & $\begin{array}{c}0.380 \\
(0.256)\end{array}$ & $\begin{array}{l}8.721 * * * \\
(2.813)\end{array}$ & $\begin{array}{c}2.866 \\
(4.196)\end{array}$ \\
\hline 4 year lag & $\begin{array}{c}0.682 * * * \\
(0.232)\end{array}$ & $\begin{array}{c}0.588^{* *} \\
(0.252)\end{array}$ & $\begin{array}{c}9.166^{* * *} \\
(2.859)\end{array}$ & $\begin{array}{c}5.346 \\
(4.271)\end{array}$ \\
\hline 5 year lag & $\begin{array}{c}0.703 * * * \\
(0.239)\end{array}$ & $\begin{array}{c}0.821^{* * *} \\
(0.324)\end{array}$ & $\begin{array}{c}9.321 * * * \\
(2.769)\end{array}$ & $\begin{array}{c}7.536 \\
(5.045)\end{array}$ \\
\hline
\end{tabular}

Notes: Table presents coefficients for 2SLS regressions of Paragraph IV challenges and settlements on generic entry according to the timing of the challenge and settlement. Columns 1 and 3 report the estimated effect of a Paragraph IV challenge with no settlement, while Columns 3 and 4 represent the estimated effects of a Paragraph IV challenge with a settlement. Each row represents the results from a different regression including different lag terms for the challenges and settlement. All estimates include warning label indicators, adverse event counts, the potential market proxy, the number of competitor molecules in the therapeutic class, the time remaining on exclusivity, therapeutic class and approval year fixed effects. Robust standard errors adjusted to allow clustering at the therapeutic class level are reported in parentheses. $\mathrm{A} *, * *$ or $* * *$ indicates statistical significance at the $10 \%, 5 \%$ and $1 \%$ levels, respectively. 
Table 6. The Estimated Effect of Generic Entry on Market Outcomes

\begin{tabular}{|c|c|c|c|c|}
\hline & (1) & (2) & $(5)$ & (6) \\
\hline \multicolumn{5}{|c|}{ Dependent variable: Log Price } \\
\hline \multirow{2}{*}{ Any Generic Entry } & $-0.397 * * *$ & $-1.433^{* * *}$ & & \\
\hline & $(0.062)$ & $(0.340)$ & & \\
\hline \multirow{2}{*}{ Number of Entrants } & & & $-0.053 * * *$ & $-0.108 * * *$ \\
\hline & & & $(0.009)$ & $(0.031)$ \\
\hline \multicolumn{5}{|c|}{ Dependent Variable: Log Total Number of Prescriptions } \\
\hline \multirow{2}{*}{ Any Generic Entry } & $0.753 * * *$ & $1.487^{*}$ & & \\
\hline & $(0.191)$ & $(0.822)$ & & \\
\hline \multirow{2}{*}{ Number of Entrants } & & & $0.107 * * *$ & $0.213 * *$ \\
\hline & & & $(0.015)$ & $(0.088)$ \\
\hline & OLS & 2SLS & OLS & 2SLS \\
\hline
\end{tabular}

Notes: Table presents coefficients for the OLS and 2SLS regressions of various measures of entry on price. The dependent variable is the price of the molecule in a given year. All estimates include warning label indicators, adverse event counts, the potential market proxy, the number of competitor molecules in the therapeutic class, the time remaining on exclusivity, therapeutic class and approval year fixed effects. Robust standard errors adjusted to allow clustering at the therapeutic class level are reported in parentheses. A $* * *$ or $* * *$ indicates statistical significance at the $10 \%$, $5 \%$ and $1 \%$ levels, respectively. 
Table 7. Simulated Welfare Impact of Settlements in Paragraph IV Cases

\begin{tabular}{|c|c|c|c|}
\hline & \multicolumn{3}{|c|}{$\frac{\text { Expected Impact of Settling a Paragraph IV }}{\text { Challenge on: }}$} \\
\hline & $\begin{array}{c}\text { Consumer } \\
\text { Surplus } \\
\text { (\$s, millions) }\end{array}$ & $\begin{array}{c}\text { Producer } \\
\text { Surplus } \\
(\$ \mathrm{~s}, \text { millions }) \\
\end{array}$ & $\begin{array}{c}\text { Deadweight } \\
\text { Loss } \\
\text { (\$s, millions) }\end{array}$ \\
\hline & \multicolumn{3}{|c|}{ All Drugs } \\
\hline Paragraph IV Challenge with No Settlement & 536.6 & -197.8 & -338.8 \\
\hline Paragraph IV Challenge with Settlement & 65.7 & -24.2 & -41.5 \\
\hline Difference due to Settlement & -471.0 & 173.6 & 297.3 \\
\hline \multirow[t]{2}{*}{ 5-Year Cumulative Difference } & -835.1 & 307.9 & 527.2 \\
\hline & \multicolumn{3}{|c|}{ Large Drugs } \\
\hline Paragraph IV Challenge with No Settlement & $1,421.0$ & -523.9 & -897.1 \\
\hline Paragraph IV Challenge with Settlement & 174.0 & -64.1 & -109.8 \\
\hline Difference due to Settlement & $-1,247.1$ & 459.8 & 787.3 \\
\hline 5-Year Cumulative Difference & $-2,211.2$ & 815.2 & $1,396.0$ \\
\hline
\end{tabular}

Notes: The table reports the simulated welfare effects of settling a Paragraph IV challenge.

Calculations are based on the average price and quantity of drugs that have not yet had any generic entry at the time that the initial exclusivity period ends (average price of approximately $\$ 768$ per prescription, 4.2 million prescriptions). The bottom panel reports estimated welfare effects for large drugs, defined as those in the top quintile of potential market). Values are calculated assuming that market demand for the drug is linear, and that the post-entry price is equal to marginal cost. The five year cumulative effects are computed under the assumption that price and quantity are stationary in the absence of entry, and that the only difference across years is the differential probability of entry according to whether or not the challenge settled. 
Table 8. Summary of Manufacturer Level Data

\begin{tabular}{lcc}
\hline & Mean & S.D. \\
\hline Research and Development Expenditures & 233 & 953 \\
(\$s, millions) & 9.22 & 60.03 \\
Patent Count & 0.03 & 0.16 \\
$\begin{array}{l}\text { Court Allows Settlements } \\
\text { Current Total Assets }\end{array}$ & 117 & 442 \\
(\$s, millions) & 0.08 & 1.82 \\
$\begin{array}{l}\text { Book Value Per Share } \\
\text { (\$s, 100,000s) }\end{array}$ & 6.87 & 23.04 \\
$\begin{array}{l}\text { Employees } \\
\text { Property Plant and Equipment } \\
\text { (\$s, millions) }\end{array}$ & 270 & 1,159 \\
& \multicolumn{2}{c}{6,305} \\
Observations & \multicolumn{2}{c}{} \\
\hline $\begin{array}{l}\text { Notes: Table reports means and standard deviations at the } \\
\text { manufacturer-year level. }\end{array}$
\end{tabular}


Table 9. Estimated Effects of Allowing Settlements on Investments in Research and Development by Pharmaceutical Manufacturers

\begin{tabular}{|c|c|c|c|}
\hline & $(1)$ & $(2)$ & $(3)$ \\
\hline \multirow[t]{2}{*}{ Court Allows Settlements } & 0.00769 & -0.0228 & -0.00127 \\
\hline & $(0.0996)$ & $(0.100)$ & $(0.111)$ \\
\hline \multirow[t]{2}{*}{ Patent Count } & 0.000141 & 0.000632 & 0.000807 \\
\hline & $(0.000704)$ & $(0.000803)$ & $(0.000899)$ \\
\hline \multirow[t]{2}{*}{ Settlement Legal*Patent Count } & -0.000188 & -0.0000409 & -0.000115 \\
\hline & $(0.000274)$ & $(0.000279)$ & $(0.000292)$ \\
\hline \multirow[t]{2}{*}{ 1-year lag: Settlement Legal*Patent Count } & & $0.000626 * * *$ & $0.000578 * *$ \\
\hline & & $(0.000216)$ & $(0.000257)$ \\
\hline \multirow[t]{2}{*}{ 2-year lag: Settlement Legal*Patent Count } & & $0.000351 *$ & $0.000490 * *$ \\
\hline & & $(0.000182)$ & $(0.000198)$ \\
\hline \multirow[t]{2}{*}{ 3-year lag: Settlement Legal*Patent Count } & & & -0.00101 \\
\hline & & & $(0.000990)$ \\
\hline \multirow[t]{2}{*}{ 1-year lag: Patent Count } & & -0.000336 & -0.0000949 \\
\hline & & $(0.00107)$ & $(0.000983)$ \\
\hline \multirow[t]{2}{*}{ 2-year lag: Patent Count } & & 0.000327 & 0.000412 \\
\hline & & $(0.00134)$ & $(0.00150)$ \\
\hline \multirow[t]{2}{*}{ 3-year lag: Patent Count } & & & -0.00131 \\
\hline & & & $(0.00140)$ \\
\hline \multirow[t]{2}{*}{ Current Assets - Total in 100 millions } & 0.00429 & 0.00343 & 0.00383 \\
\hline & $(0.0108)$ & $(0.0123)$ & $(0.0113)$ \\
\hline
\end{tabular}

Note: Table reports the results of regression of R\&D expenditures in the year against the legality of settlements, patent counts and the combination of these. Other variables include total assets and number of employees. Robust standard errors adjusted to allow clustering at the drug level are reported in parentheses. $\mathrm{A} *, * *$ or $* * *$ indicates statistical significance at the $10 \%, 5 \%$ and $1 \%$ levels, respectively. 